\title{
De venta en venta hasta El Quijote. Un viaje europeo por la literatura de Mesón $^{1}$
}

\author{
JOAN OLEZA*
}

\section{LOS CANTERBURY TALE: LA POSADA, LOS RELATOS Y EL CAMINO.}

"When in April the sweet showers fall", desde todos los rincones de Inglaterra se ponen en marcha los peregrinos "down to Canterbury". Sucedió que un día, en Southwark, en la posada de The Tabard, y al caer de la noche, se congregaron "some nine and twenty" personas, además del personaje que dice yo, Geoffrey Chaucer. Es una compañía de lo más variado, de diferentes estados, condiciones, edades, sexos... Sería difícil proponer uuna muestra más variada de la población europea del último tercio del Trescientos, pero todos estos peregrinos sustentan un audaz propósito: dar cuenta de la multiplicidad de la vida y sus relatos. Cierto que la posada es inexistente como escenografía, que es sobre todo la idea de una posada, y de una posada en la que todo resulta excelente, pero esto basta para abrir las posibilidades de una literatura de viaje que alcanzará un amplio desarrollo europeo, y desembocará doscientos y pico años después en el Quijote.

En los Canterbury Tales la posada es, sobre todo, un lugar de reunión fuera del ámbito doméstico, pertenece a la vida cotidiana, pero no a la norma: es un lugar de paso, una etapa en la aventura siempre incierta del viaje, en la que

*. Universitat de València.

1. Ponencia de clausura en Antes y después del Quijote. Valencia 2005. 50 Aniversario de la Asociación de Hispanistas de Gran Bretaña e Irlanda.

2. Cito, como es obvio, por una versión en modern english, de Nevill CoGHILL, en The Canterbury Tales, Penguin Classics, Penguin Books, 1951. 
cada viajero, lejos de sus familiares, debe convivir con gentes muy distintas, y aún distantes, y es esa cohabitación de diferentes la que incita al relato. La posada, no es aquí todavía el escenario privilegiado de las narraciones que llegará a ser con el tiempo, cede su protagonismo al camino y, sobre todo, al huésped, verdadero promotor de las mismas. Es el huésped de The Tabard, el burgués más fino de Cheapside, un hombre lleno de facundia y, a la vez, de sentido común, con un muy notable instinto de liderazgo, quien promueve el ambicioso programa de entretenimiento para el viaje de ida y vuelta de Canterbury y en el que todos deberán participar con sus relatos. La originalidad del tratamiento narrativo se pone de relieve si lo sometemos al contraste del Decamerone. Lo que en Chaucer es una posada en el camino, en Bocaccio es una villa apartada del camino. Lo que en Chaucer es un lugar donde se reúnen gentes de muy diversa condición y origen, en Boccaccio es un grupo humano homogéneo y estrictamente seleccionado. Si en Il Decamerone el escenario encerrado, protegido contra la peste, promueve las narraciones para entretener un tiempo de excepción, en los Canterbury Tales las narraciones surgen de un encuentro con la vida y su diversidad, a lo largo de la peregrinación ${ }^{3}$.

\section{LA TRADICIÓN ITALIANA: DE LAS COLECCIONES ITALIANAS DE NOVELLE A LOS POEMAS CABALLERESCOS: EL MORGANTE MAGGIORE Y EL ORLANDO FURIOSO.}

La narrativa italiana recoge $\mathrm{y}$, a la vez modifica, la representación de las posadas. Le novelle si scriveno secondo accadeno, declara Matteo Bandello (II, p. 90): lo fundamental en ellas no es ya el hecho de contar historias, sino el que las historias sucedan. El acontecimiento es el protagonista, siempre algo notable, sorprendente, ingenioso, curioso, y el arte del narrador depende de la capacidad de admirar de los sucesos que cuenta. La posada ha dejado de ser un lugar de congregación de gentes diversas, privilegiado para incitar a narrar historias, para convertirse en el escenario del juego de naipes, de algún tipo de engaño o burla, de una anécdota lujuriosa, de algún peligro o amenaza asociados al bandidaje... Esta es la fórmula del Trecentonovelle, una colección que comenzó a configurarse hacia 1392, de la que es autor el dálmata Franco Sacchetti (1332?-1400), veinte años más joven que Boccaccio. Entre sus osterie, muy frecuentes, recordaré aquella $(\mathrm{CXC})$ en la que es protagonista otro huésped, un tal Gian Sega de Ravenna, un exdelincuente que después de salvarse del patíbulo por una frase ingeniosa se reconvierte en posadero en Portocesenato. Un día se celebra en su posada una boda judía, y el huésped se

3. Hay otras posadas en los Canterbury Tales, las hay en el "The Nun's Priest's Tale" y en el "Summoner's Tale", y otra en el "Miller's Tale" que más que posada pública es la casa de un carpintero viejo y rico que aceptaba huéspedes. Estas otras posadas añaden matices importantes, que las señalan como un ámbito apicarado propicio a la delincuencia y a la anécdota libertina, matices que elaboró preferentemente la narrativa italiana. 
siente tan atraído por la joven novia que inventa una traza para hacer creer a los judíos que les asaltan unos bandoleros con la intención de matarlos y los oculta a todos dentro de un pozo ciego, donde permanecen toda una noche metidos en el cieno inmundo hasta el cuello, mientras él se entretiene, como dice un narrador muy poco amigo de judíos, "usufruttando la fanciulla e abbraciando la legge judaica quanto li piacque."

Ciento cincuenta años después ésa es la misma fórmula que utiliza Matteo Bandello, aunque con variantes importantes, que no son del caso aquí, y aún cuando entre sus más de doscientas novelle no son muchas las que hacen gravitar su intriga sobre una posada. Quizás destaca sobre todas aquella de Arnaldo el trompeta francés de Próspero Colonna (II, 50), quien en una tregua de la guerra de Lombardía, en la que ha conseguido atesorar seiscientos ducados de oro, se dirige hacia su pueblo donde espera invertir bien sus dineros y prevenirse así una vejez tranquila. Cerca ya de París se detiene en una posada y pierde al juego todo el dinero, las joyas y hasta el caballo, de manera que debe proseguir su camino como "un bel fante a piede, in colletto". Cuando llega a París, tiene que buscar el cobijo de una antigua amante, una moza de mesón reconvertida ahora en criada de la libidinosa esposa de un rico mercader, quien lo acoge amorosamente y en secreto. Allí, y desde dentro de la chimenea en la que se ha tenido que esconder para no ser sorprendido por la dueña de la casa, presencia un día una curiosa escena. Mientras espera a la dama, su joven y rico amante se desnuda de todas sus joyas y de una bolsa repleta de escudos, entonces llega ella y se desnuda también y se inician los juegos de amor y de mimo. Ella le pregunta cómo ha tardado tanto en ir a visitarla y qué ha hecho durante el día, y él, entre besos, le contesta que ha tenido que ir al castillo de la Tournelle a presenciar correr el anillo, y como ella no sabe en qué consiste el juego, él le explica que consiste en una justa en que los jinetes, lanzados al galope de su caballo, tienen que ensartar con su lanza un anillo suspendido en el aire. La dama, súbitamente inspirada, le pide que haga con ella la prueba, que corra y vea si puede ensartarle el anillo, pero por más que voluntariosamente lo intenta el joven no consigue que sus carreritas acaben donde deben, provocando las burlas de la señora. El joven se justifica entonces diciendo que le falta la trompeta, y que si sonara él acertaría de pleno. Se oye entonces un bramido aterrador que grita: ¡Por la trompeta, que no quede!, y salta un demonio ennegrecido afuera de la chimenea, haciendo sonar su trompeta. Los

4. Il trecentonovelle (1970). Otras narraciones que tienen por escenario una hostería son las que se refieren al ocurrente huésped Basso delle Penne (VI y XXI), aquella en que la hostería es un precario refugio en un territorio infestado de bandidos (XVII), o la estupenda novella CXL, en la que una cuadrilla de mendigos ciegos elige una posada para repartirse los beneficios recaptados en las fiestas de Pisa y acaban a palos unos con otros, para beneficio del huésped y su mujer que se quedan con todo. Otro relato singular es el de la novela XXXI, en la que dos embajadores de Casetino, enviados en misión ante el obispo Guido d'Arezzo, se detienen en un albergue donde comen y beben tan a su gusto que acaban por olvida el mensaje que se les había encomendado. Tratando de recordarlo, dejarán pasar los días, las digestiones y las libaciones, hasta que finalmente tendrán que presentarse ante el obispo con la memoria en blanco. 
amantes huyen despavoridos, y así es como Arnaldo pudo volver a su casa más rico y mejor vestido de lo que había salido de la guerra ${ }^{5}$.

En este universo de las novelle, lleno de referencias a personajes, acontecimientos y lugares de la actualidad más inmediata, que los lectores -a quienes el novelista se dirige con familiaridad-identifican fácilmente, la narración se complace en los ambientes y costumbres contemporáneas (especialmente las que se refieren a la alimentación y al acomodo de viajeros y cabalgaduras) y en la presentación de personajes ingeniosos, ocurrentes, llenos de chispa verbal. Los viajeros componen una muestra bien diversificada: mercaderes, judíos, mendigos, clérigos, burgueses, soldados... gente de paso, en suma. Estas ventas o posadas tienen poco que ver con la imagen que, procedente de la tradición oral y de los relatos de viajeros, se extendió como un tópico por toda Europa y que estudió M. Joly (1982), en un trabajo monográfico y bien documentado. Aquí los huéspedes no suelen ser ladrones o exdelincuentes, y en las hosterías no se engaña con los alimentos o el vino bastardeados, ni se estafa con precios abusivos, ni se tortura con alojamientos inconfortables y sórdidos.

En los poemas caballerescos de materia carolingia la posada, ahora generalmente rural, despliega nuevas posibilidades. Se convierte en variante del castillo, pues en el vagar incansable de los caballeros de Carlomagno y de Agramante siempre hay una venta o un catillo en que hacer descansar y reponer las cabalgaduras y un huésped con el que hacer amistad o enemistad. La venta, en particular, deviene una experiencia cotidiana, y el poeta transcurre por ella, a menudo, sin reparar en ella, pero cuando se demora su canto evoca escenas memorables.

Así ocurre en el Canto XXI del Morgante Maggiore (1482-83), del florentino Luigi Pulci, en el que Astolfo socorre a un huésped a quien el tirano señor de Corniglia, en Barberia, el gigante Chiaristante, que había usurpado el trono y sustituído todas las religiones por el culto a sí mismo, amenazaba con arrebatarle sus bienes, su posada, su vida y su hija, si no le cedía de buena gana a ésta como concubina: Astolfo derribará en duelo a Chiaristante, mientras que Orlando, que ha llegado también a Corniglia, pero que "non aveva moneta" para pagar la posada y que consigue escapar a duras penas del huésped que le exige el pago, se presenta a tiempo de contemplar el duelo y rematar al tirano. El pueblo, liberado por fin, se lanza sobre el cadáver del tirano y lo despedaza a bocados, acto seguido eleva a Astolfo al trono, no sin que el poeta, escéptico ante el espectáculo, comente que ese mismo pueblo que lo eleva mañana podría crucificarlo. Pero si en este canto domina la nota heroica, y vemos a los paladines ejecutar una hazaña ejemplar, en el Canto XVIII dominan las notas burlescas y apicaradas, tan características de este poema. En este canto

5. Cito por la edición de Delmo MAESTRI de las cuatro partes de Le novelle ( 1992-1996). La novela III, 41, resulta muy próxima a los argumentos de las commedie contemporáneas, con su escenificación de un encuentro, en una posada, y ante un pato asado al ajo, entre un soldado español fanfarrón y un ingenioso gascón, de nombre en miniatura, Pissinicolo. 
se encuentran y deciden continuar juntos los dos protagonistas más singulares del poema de Pulci, el gigante Morgante y el maligno semigigante Margute. Morgante observa que para vagar por el mundo tienen entre los dos "pochi danar”, lo que le preocupa pues él siempre ha pagado a sus huéspedes. Margute, por el contrario, siempre ha robado cuanto ha necesitado gastar, y le aconseja a Morgante hacer lo mismo. El episodio que sigue no hace más que poner en práctica la fórmula de Margute, pero de una manera extraordinariamente astuta y devastadora, pues caen sobre una venta como una plaga de Egipto, y cuando salen de ella no queda nada en pie, pues Margute, que se ha pasado la noche torturando psicológicamente al huésped, y disfrutando con ello, quema todo lo que no podía cargar en sus alforjas. Mientras se alejan del desastre, Morgante echa a rodar su carcajada de trueno y exclama: "Or mi piacesti tu, Margute mio!".

Son bastantes los ecos que estas escenas del Morgante Maggiore dejaron en el Quijote,ya en motivos concretos (el reiterado conflicto entre venteros y caballeros por la falta de dinero con que estos recorren el mundo; o el de la pesadilla que la visita del caballero representa para un ventero que preferiría perdonar el pago del hospedaje y olvidar los destrozos, con tal de que se marchara pronto), ya en esa perspectiva paródica tan característica en uno u otro textos. También los dejó, y sin duda en mayor número, el Orlando furioso, treinta y tantos años posterior en su primera versión (1516) al poema de Pulci. En uno de sus episodios, contado de forma reiteradamente interrumpida en los Cantos XXVII y XXVIII, la venta reitera su condición de escenario de burlas y engaños notables, y recupera la de lugar propicio para el relato, que trata de una de esas historias libertinas tan degustadas por la tradición italiana. Quien narra es el propio mesonero, a quien a su vez le contó la historia un viajero veneciano, y lo que narra a sus huéspedes es un episodio del que espera que saquen su lección bien aprendida sobre la lealtad de las mujeres casadas. Muy cervantinamente el poeta preludia el relato pidiendo a las damas que no lo lean pues trata de su infamia y desmarcándose él mismo, pues él siempre amó y sirvió a las damas, como tiene bien demostrado. En el relato dos jóvenes, uno de ellos el Rey de Lombardía y el otro un rico ciudadano romano, ambos de una hermosura extraordinaria comprueban que, pese a ello, sus respectivas esposas les engañan, y lo hacen la una con un despreciable criado y la otra con un enano mostruoso. Lejos de tomar venganza en ellas, pues llegan al convencimiento de que a una mujer no le basta un hombre solo, acuerdan emprender un viaje libertino por toda Europa -incluyendo "la terra de l'Inglesi"- y obrar en consecuencia con lo que han visto, dedicándose a comprobar en la práctica que las esposas de los otros no son más fieles que las suyas. Es así como llegan a Valencia y conocen, en una posada del Grao, a la hija del posadero, una joven bella en extremo, que se llama Fiammeta. Ellos dos, ya cansados de libertinaje, habían llegado al acuerdo de quedarse con una sola mujer, pero para evitar ser engañados de nuevo la compartirían sin celos ni envidias. Así ella tendría dos hombres y ellos podrían perpetuar su amistad. Y tal como lo piensan lo ponen en práctica con Fiammeta, una vez que su padre la autoriza 
a marchar con ellos. Pasan los días en completa felicidad hasta que un día llegan a Xàtiva y se alojan en un mesón donde Fiammeta se encuentra con que el mozo es un joven que había crecido con ella y compartido sus juegos infantiles y también su lecho. Después de lamentarse el joven de su suerte y de solicitarla insistentemente en nombre de su amor, la joven acepta recibirlo esa noche, aunque le advierte que duerme en medio de los dos hombres. En una deliciosa narración el poeta cuenta cómo esa noche el mozo se acerca a oscuras y a tientas al lecho donde duermen los tres amantes y cómo colándose entre las piernas de Fiammeta, que estaba de espaldas, la "cavalcó forte" durante toda la noche y sin mudar postura, pues no convenía para el secreto de la hazaña. Ninguno de los dos amantes rechista, pensando que es su amigo el que trabaja, pero a al día siguiente, cuando uno y otro se comentan jocundamente la larga noche de galopes descubren que ninguno de los dos fue el jinete. Cuando finalmente llegan a saber de labios de Fiammeta lo ocurrido, y tras su inicial estupefacción, se echan a reir a carcajadas. Su conclusión no puede ser más sensata: si a esta moza no le han bastado dos hombres que siempre la tenían abrazada y regalada, nadie está libre de ser engañado por su esposa. Así que casan a Fiammeta con el mozo del mesón y ellos regresan a sus casas junto a sus amadas esposas, con las que nunca más volvieron a tener un disgusto.

\section{El TEATRO DEL Siglo XVI: DE GIL ViCENTE A LOPE DE RUEDA.}

En el teatro español del siglo XVI las escenas de venta no llegan a constituir un recurso definido, y apenas encontramos alguna notable. Evocaré la del Auto da alma, de Gil Vicente, representada en 1508, en el que la posada tiene un valor alegórico que el poeta glosa en el Argumento: es la posada en la que el alma tiene que hacer parada, en el camino de la vida, en el que es asaltada continuamente por las tentaciones del demonio, para reponer sus fuerzas y continuar después avanzando. "Esta estalajadeyra das almas he a madre Santa Ygreja", que en la representación servirá al alma "manjares guisados por Deos Padre" en una mesa-altar servida por cuatro doctores de la Iglesia, y pagados por el Hijo en la cruz. Gil Vicente descubre así el potencial simbólico de la posada, aunque sea en clave divina. Más de un siglo después, en 1631, Rodrigo Fernández de Ribera invertirá la clave simbólica a lo humano en su Mesón del mundo.

Pero la posada, a pesar de ese potencial simbólico que le confiere su condición de etapa o parada provisional en el camino de la vida y que la acompaña siempre, parece exigirle a la literatura europea un decorado, unos personajes, unas intrigas y hasta un lenguaje más impregnados de materia cotidiana y realista. Así sucede con La Farsa de la ventera en que se representan algunos engaños que algunas suelen usar con que a las vezes roban a los caminantes, de Diego Sánchez de Badajoz, que nos devuelve a la venta como lugar idóneo 
para una acción desvergonzada, de cruda lucha por la vida, en la que la astucia, el embaucamiento, la extorsión y el hurto están a la orden del día. Ahora sí nos encontramos con el tópico europeo de la venta como "lieu privilegié de tromperie", como escenario de "la bourle", cuya tradición estudió M. Joly (1982). Es obvia la cercanía del texto de Sánchez de Badajoz a las fuentes del folklore y a las representaciones costumbristas de la realidad. En un clima pastoril rústico, enturbiado por oscuras nubes de protesta social, asistimos a las maniobras con las que una ventera, valiéndose de los encantos de una negra esclava suya, atrae a los viajeros, un rico avaro y un pobre generoso, trata con ellos el precio de lo que va a ofrecerles de comer y de beber, coacciona al rico con amenazas de denunciarlo a la justicia por su dinero no declarado, hasta sacarle mucho más del que quería gastarse, y emborracha al pobre, le roba más de cien ducados que llevaba consigo, y después le denuncia con falsedad al alguacil por no querer pagarle lo consumido y por haber intentado forzarla. Afortunadamente para la causa de la justicia, la intervención de un "diablo muy feroz" viene a poner las cosas en su sitio.

En la generación de los autores-actores Lope de Rueda es quien acoge la escena de posada en una de sus piezas, la más italianizante de todas, Los engañados, versión libre de Gl'Ingannati, la célebre comedia colectiva de los Intronati di Siena, que fue representada por ellos en 1531 y publicada en 1537. En la pieza italiana asistimos a una estupenda escena (III-2) en que dos mesoneros vecinos, Frulla, el del mesón Il Matto, y Agiato, el del mesón Lo Specchio, se disputan, en plena calle, a los viajeros, Fabrizio y sus dos sirvientes, el Pedante y el simple Stragualcia. Los dos mesoneros, a un lado y a otro de la calle, a la puerta de sus respectivos mesones, compiten en ofrecimientos a los viajeros, cada uno se vanagloria de su prestigio y de su clientela y denigra los del competidor, mientras el Pedante se complace en alimentar la discordia, sin acertar a decidirse por ninguno de los dos. El simple, que lo escucha todo, se desespera, la boca hecha agua, con las promesas de vino y de exquisitos manjares que revolotean en la facundia de los venteros, hasta que no puede más y se mete en la cocina de Frulla y allí, ante la abundancia que se le ofrece, se jura a sí mismo que nadie le moverá del lugar. Por eso es él quien decanta la decisión cuando, para vencer las eternas dudas del Pedante, le hace saber que en la cocina de Frulla ha visto a un jovencito "bello come uno angiolo", argumento que tan pronto como se enuncia persuade al incordiante Pedante. Más tarde y ya fuera de la hostería, presenciaremos una feroz batalla dialéctica entre los dos servidores, que ponen fuego a toda la cohetería verbal propia de esos dos arquetipos cómicos tan experimentados por el primer teatro italiano, y que se arrojan a la cara pullas, insultos y recriminaciones de todos los calibres.

En la pieza española se elimina la disputa de los dos mesoneros, que se funden en uno solo, Frulla, de manera que Fabricio no tiene que decidir en qué posada se aloja pues ya está en ella la primera vez que accede a la escena. Lope de Rueda, más interesado en dar suelta cuanto antes a la comicidad de su simple, reduce la posada a decorado del simple, el lugar en el que se des- 
hará en quejas contra su señor Fabricio y contra el ayo Quintana, por haber madrugado para salir pronto a la calle, sin cuidarse de almorzar. Desolado, Salamanca se pregunta: “¿Esso meresce el pobre Salamanca por irse a dormir al pajar y ahorrar de cama?”, y amargamente se lamenta: “¡Oh, pobre de ti, Salamanca! ¿Dónde irás agora, solo y en tierra agena, y sin almorçar, ni quien te convide?" Una muy desdibujada sombra del modelo italiano, a la postre.

\section{La COMEDia NuEVA. Lope DE VeGa Y LA COMEDIA DE MESÓN ${ }^{6}$.}

Tampoco el teatro posterior parece interesado en explotar las posibilidades de juego escénico de la posada. Ni en Juan de La Cueva, ni en Cervantes, ni en los valencianos aparecen escenas significativas. Guillén de Castro incluso hace desaparecer la venta de las historias amorosas de Dorotea y Cardenio en su versión de Don Quijote de la Mancha. Lope, en cambio, aparece desde muy temprano interesado por estas posibilidades, que explora en piezas como Los donaires de Matico, y tras él no será ya raro encontrar escenas de posada o de mesón. Vale la pena evocar El tejedor de Segovia, de Juan Ruiz de Alarcón, y piezas de Tirso como La huerta de Juan Fernández, Por el sótano y el torno o Antona García, en la que en una escena muy singular la ventera ayudará a parir a un par de gemelos a la bravía Antona. Pero más allá de las escenas sueltas en esta o aquella obra dramática, la mayor aportación de la Comedia Nueva a la literatura de mesón son tres comedias de mesón, dos de Lope, El mesón de la corte (1588-1595) y La noche toledana (1605), y otra, La ilustre fregona y amante al uso, versión de la novela cervantina, que muy probablemente no es de Lope, aunque le fue atribuida ${ }^{7}$. No trataré en profundidad estas obras, porque el tiempo no da para más, pero sí de caracterizarlas en sus aportaciones básicas. Se trata en estas obras de mesones urbanos, no de ventas rurales, bien caracterizados por un intenso costumbrismo, en el que es posible sorprender la vida cotidiana del mesón, desde la tablilla de reclamo en la calle hasta las faenas de mozas y mozos de servicio. Alrededor de ellos la vida de la ciudad, Madrid o Toledo, se perfila con bastante precisión, incluso en sus aspectos turísticos, muy promocionados por cierto. La acción se estructura por medio de una sucesión de llegadas de diversos personajes (damas, galanes, soldados, servidores, ancianos caballeros), cada uno cargado con su historia a cuestas (el caballero que huye de otra ciudad por una muerte que ha causado

6. Este apartado sobre el teatro español ha sido desarrollado con mayor amplitud en mi artículo "Mesones de teatro", en el Homenaje a Marc Vitse, Universidad de Toulouse-Le Mirail, 2006.

7. La obra aparece atribuida a Lope en su edición original, la Parte XXIV (la de Zaragoza, 1641). CotARElo (1928, pp. XXII-XXIII), no obstante, descarta la atribución a Lope, al editarla. MorLEY y BRUERTON (1968, pp. 480-881) clasifican la obra entre las de "dudosa" atribución a Lope. Vuelve sobre el tema M. GARCía MARTín (1980, p. 148), que sin añadir ningún elemento nuevo, se decanta por la atribución a Lope. 
en un duelo de amor y que trata de pasar a Flandes o a Italia como soldado; el anciano que sale a buscar a su hija o a su hijo, que han desaparecido o huido del hogar...), todas las cuales convierten el mesón en un lugar de reunión azarosa, donde todos los encuentros y todas las sorpresas son posibles. En estos mesones acomodados les acogen un mesonero que gusta exhibir su honorabilidad, y una moza de mesón "más que criada y menos que hija" (en expresión de Mateo Alemán, en el Guzmán), una "gallarda fregona" en quien la comedia centra toda su atención. Sirve de señuelo a los viajeros, que la asedian en tropel, pero la caracteriza un toque de distinción, una inaccesibilidad burlona, que se debe a su origen secreto de dama de noble cuna. En El mesón de la corte interviene además un falso mozo de mesón, que en realidad es una dama disfrazada que ha salido en persecución de su seductor, y que actuará siguiendo el guión de lo que yo he bautizado en otros lugares como la dama donaire, la dama llena de ingenio que envuelve a todos los demás personajes en una trama de invenciones que conduce al desenlace, que siempre resulta en su beneficio.

El mesón de Lope es un mesón de amores, un lugar en el que se congregan jóvenes y viejos de distinta condición y estado para entregarse no a contar historias, ni a cometer fechorías, sino a dar rienda suelta a sus deseos, a jugar con muy variadas cartas los múltiples juegos de la seducción, que por un momento, y en este escenario encantado y fuera de la norma, libera de las ataduras sociales y familiares. Todos sienten unos mismos deseos, criados y señores, padres e hijos, estudiantes y mozos de mesón, y todos se vuelcan en él, cada cual con sus armas y sus máscaras. Porque el mesón es el reino de las máscaras y de las metamorfosis: la mayor parte de los personajes llegan a él con la máscara puesta, pero son muchos los que o se la cambian allí mismo o se la ponen por primera vez. Se cambia de nombre, de aspecto, de vestido, y sobre todo de identidad. Nadie es lo que aparenta ser y la vida, tal como fluye por las estancias del mesón, se parece más que nunca a una representación carnavalesca, y nos otorga la ilusión de ser lo que no somos. De ahí que el mundo al revés que la comedia propicia permita explorar transgresiones imposibles en la vida regulada por la norma: el deseo incestuoso de un padre por quien no sabe que es su hija; el papel de alcahueta que una hija juega respecto de su padre; el erotismo hermafrodita, protagonizado por la dama donaire, que con su aspecto de mozo capón, de galán lindo, enamora a otras damas y da lugar a escenas de un erotismo tan encendido como ambiguo; el jugueteo en escena con el pecado nefando, entre varones, que a oscuras y entre risas son metidos en un mismo lecho, cada uno convencido de que el otro es una moza; la transgresión de los papeles sociales, con criados que se hacen servir de señores, o que incluso castigan físicamente a sus aparentes señores, o nobles que se disfrazan de humildes mozos de mesón y se dejan humillar por los viajeros. Como en el Quijote, estos momentos de desorden se complementan a menudo con escenas entremesiles, en las que abundan los palos y los gritos, y que alcanzan en La noche toledana una muestra genial, la de la larga noche de desastres que tienen que padecer los protagonistas, una noche en verdad toledana. 
Cierto que ese momento de proliferación y de diseminación del desorden más allá de la norma social se irá canalizando gracias a la trama que inventa y ejecuta una doncella, en apariencia la más desamparada, la que actúa desde una posición de mayor fragilidad, pues ha sido deshonrada y abandonada y ha tenido que huir lejos de los suyos. Pero en estas comedias de Lope siempre resulta difícil decidir qué propone con más fuerza la comedia, si la jubilosa complicación del desorden o su simplificación final en el orden restaurado. Habrá diversas opiniones, y yo tengo la mía, que expresé en otros lugares (Oleza 1990 y 1995). Lo cierto es que cuando la trama de la dama donaire conduce a esa gran escena final de equívocos, donde cada personaje yace con quien no querría yacer, sin saberlo, es el momento elegido para hacer entrar a los alguaciles, que irrumpen en el mesón y desoyendo las protestas de honorabilidad del huésped hacen sacar de sus habitaciones una por una a todas las parejas. Sólo un personaje, la dama donaire, ha conseguido tener entre sus brazos a quien quería tener, al amante que le correspondía, el que la sedujo y abandonó, y la comedia la recompensará con la boda. Los alguaciles, por su parte, y una vez ponderada la situación, casan a todos los casables y dan por zanjado el asunto. En La noche toledana, al disponerse todas las bodas se manda también casar a Beltrán con Riselo y al Alférez con el Capitán: es la gran carcajada carnavalesca con que Lope despide la obra.

\section{El teatro isabelino. Shakespeare o el Ámbito de SIR JOHN FALSTAFF.}

También el teatro isabelino exploró a fondo las posibilidades de la posada como escena dramática. Están las obras de Shakespeare en primer lugar, las dos partes de King Henry The Fourth y la inmediata comedia de The Merry Wives of Windsor, las tres anteriores a 1600. Pero un rápido repaso del teatro inglés contemporáneo ${ }^{8}$ llama la atención sobre algunas otras obras, como la anónima The Merry Devil of Edmonton, de esa misma época y representada en The Globe por los todavía Chamberlain's Men, que tiene muchos elementos en común con The Merry Wives of Windsor; un poco posterior es The Knight of the Burning Pestle, de Francis Beaumont, representada ya en el Blackfriars Theatre, en la que es muy evidente la influencia del Quijote de 1605. De un período posterior son Love's Pilgrinage, en la que la dama se disfraza de varón para seguir los pasos de su galán, y The Fair Maid of the Inn, ambas de John Fletcher, pero sobre todo la sofisticada The New Inn, or The Light Heart, de Ben Jonson, representada en 1629 por los King's Men en el teatro Blackfriars, con sus identidades enmascaradas, su juego de teatro dentro del teatro y su asamblea de personajes en la posada de The Light Heart en Barnet.

8. Repaso que no podría haberse hecho de la misma forma sin la ayuda experta del profesor Jesús Tronch, de la Universitat de València. 
Me limitaré a una breve consideración de las tres piezas de Shakespeare pues aportan toda una dimensión nueva a la literatura de mesón. En la comedia, la última en ser escrita de las tres, se establece toda una dialéctica de tesis y antítesis entre el hogar burgués de Mrs. Ford y The Garter Inn, traducida al castellano como la Hostería de la Jarretiera. La contraposición de ambos espacios simbólicos encuentra zonas de transición en las calles de Windsor y su síntesis o desenlace en el Windsor Parc del quinto acto. El espacio del hogar es la fortaleza del matrimonio burgués, defendida por Mrs. Ford, con la colaboración de Mrs. Page y la ayuda eficacísima de una alcahueta monjil, Mrs. Quickly, que gestiona los engaños de las damas con un atildamiento puritano verdaderamente persuasivo. Pero se trata de una comedia y esa defensa no tiene nada de numantina, y sí todo de muy burlona.

En el espacio antitético, en la Garter Inn, hay un huésped que recuerda al de los Canterbury Tales, jovial y facundo, que trata con alegre camaradería a su residente Sir John Falstaff, pero que tiene una indiscutible autoridad entre sus conciudadanos, pues media entre dos insignes burgueses, un párroco galés (Sir Hugh Evans) y un médico francés (el doctor Caius), aunque sólo sea porque domina mucho mejor que ellos la lengua inglesa, para evitar un duelo. Siempre dispuesto a la broma, sabe no obstante tomar partido por la causa más noble y ayudar a la pareja de jóvenes amantes a burlar las intrigas de los padres de ella para que se case con candidatos que ella no ama. La Garter Inn es una posada honorable y si alguien comete un robo en ella no es desde luego el mesonero, sino un falso Duque alemán y sus colegas, three German devils, que lo afanan sus caballos.

Pero el verdadero protagonista de la Garter Inn es el libertino sir John Falstaff, ese personaje extraordinario que los espectadores ya conocían de las dos partes de King Henry The Fourth, y que aquí aparece tan acuosamente gordo como allí, tan amigo del vino de Canarias, tan vacío de bolsa y lleno de deudas, tan fanfarrón, y tan embustero . La novedad es que aquí un Falstaff bastante más crédulo que allí pretende llenar su bolsillo pelado gracias a la seducción de sendas damas burguesas, de las que sospecha que manejan el dinero de sus maridos: "Seré el explotador de ambas y serán mis tesoreras. Las tendré como a mis Indias Orientales y Occidentales y comerciaré con ellas"9. Su honor es un valor tan laxo aquí como allí, y él está tan pronto dispuesto a enarbolarlo como una bandera, a utilizarlo como coartada o a excusarse por tener que prescindir de él dadas sus necesidades: “'Granuja! -le espeta a su compinche Pistol- ¡Te montas en tu honor, monstruo de bajeza, cuando apenas si puedo yo mismo, que te estoy hablando, guardar los límites rigurosos del mío! Yo, yo, yo mismo, dejando a un lado el temor de Dios y ocultando mi virtud detrás de mis necesidades, me veo obligado a engañar y recurrir a ciertos expedientes" $(817, b)$. No obstante, la adhesión de Shakespeare a su personaje ha decaido en esta comedia, que impone con excesivo rigor puritano el

9. Cito por la traducción en prosa de L. Astrana Marín, en Obras completas (1943). 
triunfo de las virtudes domésticas y burguesas sobre el viejo libertino ${ }^{10}$. Aquí Falstaff es mucho más ingenuo y crédulo que en los dramas. Le engaña Mrs. Quickly, le engaña Mr. Ford, le engañan las dos damas, y hasta llega a creer que quienes le pinchan y chamuscan en el parque son hadas y duendes de verdad.

En todo caso la posada es aquí, como dice el posadero: "his chamber, his house, his castle, his standing-bed and trucked bed", la posada en definitiva se ha reconvertido en el ámbito material, pero también simbólico, de un personaje excepcional, que desborda con mucho a sus predecesores, los venteros o pasajeros ocurrentes de la narrativa italiana.

En los dos dramas dedicados al rey Henry IV esto es todavía más verdad, pues el personaje exhibe todos sus matices y se ofrece a todos los contrastes de puntos de vista en, al menos, cuatro facetas muy elaboradas. La primera de estas facetas es la del Falstaff ladrón, que se manifiesta sobre todo en la First Part, en el robo de Gadshill a los peregrinos de Canterbury. Aquí, Falstaff, con su portentoso ingenio verbal, es capaz de embellecer su medio de vida. Nosotros, proclama: "that are squire of the night's body [...] Diana foresters, gentelmen of the shade, minions of the moon [...] our noble and chaste mistress the moon, under whose countenance we steal". Pero en esta dimensión el universo de las posadas, tanto la de Rochester como la de Eastcheap, está marcado por la picaresca y la delincuencia, y no se contrapone tan nítidamente al de palacio como al de los hogares burgueses de Windsor, pues el Príncipe heredero juega en los dos lados, y en esta First Part más incluso en el lado de la posada que en el del palacio. No tiene nada de extraño que Falstaff trate de asegurarse la complicidad del Principe de Gales como garantía de futuro: cuando sea rey, le dice en varias ocasiones, no cuelgues a los ladrones.

En la segunda faceta, la de la guerra, la posada juega un papel menor, aunque es en ella donde el príncipe le encarga reclutar y ponerse al mando de una compañía de soldados (I, III, 3). Hace su aparición entonces el Falstaff corrompido que comete fraude con el reclutamiento de soldados y se embolsa los beneficios, o el Falstaff más cínico, que no duda en reclutar como soldados a los mozos más desdichados e inútiles y convertirlos después en carne de cañón ${ }^{11}$, si ello le reporta unas libras, y también el Falstaff más cobarde, el más fanfarrón, el más mentiroso, el que se olvida de llevar consigo la pistola porque ha metido en su funda una botella de vino de Canarias o el que apuñala el cadáver de Percy para hacer creer a todos que es él quien lo ha matado.

En la tercera dimensión está el Falstaff que más nos interesa, el que vive en la posada de The Boar's Head, que regenta Mrs. Quickly. En ella Falstaff es el adorador de Baco, bajo la forma de vino de Canarias o de Jerez seco, y

10. Ese triunfo que se remacha explícitamente en el cuadro final del parque, en el que el espectador puede escuchar los improperios que dirigen al burlado y descalabrado Falstaff los burgueses de Windsor, enumerados como en un inventario moral de perversiones.

11. De sus ciento cincuenta soldados no sobreviven más que tres "y esos, destinados a mendigar el resto de sus vidas"(275b). 
un maldiciente que habla mal de todos, y en especial del príncipe, siempre que esté ausente, por supuesto, pues cuando está presente no duda ni un instante en desdecirse de todo lo que ha dicho o en darle la vuelta y convertir las murmuraciones en obsequiosos halagos. El clima en la posada se hace sórdido, de agria disputa doméstica, sobre todo en la Second Part, con una Mrs Quickly que demanda al caballero ante la justicia por haberla nada menos que apuñalado, por haberla arruinado, pues "ha devorado mi casa y mi comercio entero; me ha engullido toda mi substancia en su oronda barriga", pero sobre todo por no haberle cumplido el juramento de hacerla su señora esposa. También con Doll Tearsheet, su amancebada, la porfía es ruín: los gritos, los insultos, vuelan, sale a relucir la navaja, el lenguaje alcanza una crudeza insospechada en una mujer, pero todo se resuelve en pura cohetería, pues Falstaff sabrá calmar a sus mujeres, mimarlas, conseguir nuevos fondos (Mrs. Quickly está dispuesta a vender su propio vestido, para ello) y hasta no se sabe si la promesa o la amenaza de Doll Tearsheet de zarandearle entre las sábanas. En la Second Part el lenguaje, los gestos, los sucesos (un asesinato cometido por Pistol y las dos mujeres), propician una atmósfera más de bajos fondos, más cercana a la picaresca, pero sea cual sea la medida de esta degradación, Falstaff aparece ahora en su aspecto doméstico, como un marido arrufianado y compartido.

La cuarta y última dimensión es la que envuelve a la vez al caballero apicarado y al heredero de la corona. Es una relación sorprendente, un hallazgo de Shakespeare, con momentos brillantísimos, como aquel del Acto II de la Primera Parte en que ambos representan una pequeña escena teatral, en la cual primero Falstaff hace de Rey y recrimina al Príncipe su modo de vida, y después se intercambian los papeles, pasando el Príncipe a hacer de Rey y a acusar a Falstaff. La extraña camaradería entre ambos, que en el caso del Príncipe incluye repetidas burlas, insultos, desprecios, desmentidos, desautorizaciones, órdenes terminantes y hasta amenazas, pero también esa especial clase de amor que se manifiesta en su tristeza cuando, al final de la Primera Parte, cree muerto en la batalla al gordo caballero, tiene probablemente mucho que ver con la condescendencia que el propio Henry, o Hal, como le llama Falstaff, siente por su propia juventud, disipada en una vida poco honrosa que percibe con sentimiento de culpa pero a la vez con gozosa voluntad de perseverar en ella por lo menos hasta que su acceso a la corona le imponga un cambio radical de actitud. La guerra, al final de la Primera Parte, marcará el cambio de rumbo de su vida, el comienzo del camino hacia la dignidad del trono y su progresivo abandono de la vida picaresca.

En la Segunda Parte el conflicto se agudiza, al aparecer la antítesis de Falstaff en la figura del Justicia Mayor. Entre los dos se libra una batalla simbólica en medio de la cual se encuentra el Príncipe. El Justicia Mayor acusa a Falstaff de haber extraviado al joven Príncipe, de ser su ángel malo, y el Rey ordena que sea separado del heredero. En el Acto IV de esta Segunda Parte, el Príncipe está ya muy lejos de Falstaff, y así lo hace constar al Rey junto con su arrepentimiento. La muerte del Rey y el acceso del príncipe a la corona son el transfondo de una escena espléndida y cruel, con la que culmina la obra. Al 
enterarse de la muerte del Rey, Falstaff corre a celebrar la subida al trono del Príncipe, de su príncipe. Está convencido de que ha llegado su hora, la de su triunfo, la de su influencia sobre el poder, la de su riqueza, y promete repartir con sus amigos esta bienaventuranza. Que tiemble el Justicia Mayor. Plantados en la calle él y sus secuaces esperan la llegada del nuevo Rey, pero cuando éste aparece al frente de su séquito lleva a su lado al Justicia Mayor y al pasar ante el caballero pícaro, y escuchar sus ilusionados vítores, se detiene para hacerle escuchar su derrota definitva: "I know thee not, old man [...] I have long dream'd of such a kind of man,/ so surfeit-swel'd, so old, and so profane;/ But, being awaked, I do despise my dream [...] Presume not that I am the thing I was/ for God doth know, so shall the world perceive, / that I have turn'd away my former self;/ so will I those that kept me company". El Rey destierra a Falstaff, bajo pena de muerte, a mantenerse lejos de él, a diez millas de su persona.

La derrota de Falstaff ante el trono se ha consumado, como se consumó también ante el orden burgués en Windsor, pero el Rey es más benigno que los burgueses. Ahora el Rey proporcionará a Falstaff medios de vida, a fin de que la falta de recursos no le arrastre de nuevo al mal, e incluso deja abierta la puerta para una posible regeneración, que si se cumpliera el Rey sabría recompensar. Lo que es seguro es que el Rey Henry the Fifth nunca volvió a The Boar's Head Inn en Eastcheap.

\section{GuZMÁN de ALFARACHE. LA POSADA Y LA VIDA.}

La publicación en 1599 de la Primera Parte de Guzmán de Alfarache supuso un ensanchamiento considerable de la literatura de mesón y de viaje, pero sobre todo una nueva perspectiva de la misma. Mateo Alemán resitúa los episodios de posada a lo largo de una vida, entretejiéndolos en ella, como sus eslabones. Ya no se trata de momentos extraídos de la norma como treguas en la vida cotidiana, sino de momentos que configuran la vida cotidiana, que pasan a pautar su continuidad. "Vas caminando por desiertos, de venta en venta, de posada en mesón", dice Guzmán de sí mismo en la Segunda Parte (1983, p. 618), y a lo largo de las dos que tiene el libro el pícaro se detendrá en multitud de posadas, rurales unas, ventas solitarias en medio de los campos, urbanas otras, en suelo español o italiano, unas excelentes, otras repugnantes, honestas unas y tramposas otras.

La primera aventura del niño Guzmán sucede en una venta, y la segunda también, y dejarán marcada su vida entera, hasta el punto de que muchos años después, cuando vuelve a su lugar de origen, Sevilla, y a medida que se va acercando a la ciudad "se me refrescó la memoria cuanto allí me pasó cuando de Sevilla salí [...] Representóseme de aquel principio todo el discurso de mi vida, hasta en aquel mismo punto. Acordéme de la ventera y de la venta, donde me dieron aquella buena tortilla de huevos y el machuelo de Cantillana" (p. 848). 
Se ha analizado la experiencia de Guzmán en estas dos ventas, con las estafas que sufre en ellas, como un episodio iniciático en su biografía y en su formación como pícaro, y no me caben dudas sobre ello. El muchacho que, en la coyuntura de la crisis familiar provocada por la muerte del padre y los apuros crecientes de la madre, decide salir de casa, era un muchacho "vicioso y regalado, criado [...] sin castigo de padre [...] cebado a torreznos, molletes y mantequillas y sopas de miel rosada, mirado y adorado, más que hijo de mercader de Toledo, o tanto" (p.146). Y si sale de la protección de la casa familiar hacia la aventura es porque "alentábame mucho el deseo de ver mundo" (p.146). El repugnante revoltijo de huevos y huesecillos de pollo a medio incubar, o los no menos repugnantes platos de lengua y sesos del machuelo, así como el robo de la capa, la suciedad del servicio y la jeta brujeril de la primera ventera, o la hipocresía y la cobardía del segundo ventero, y las pulgas que se ceban en él en su posada, son la puerta por las que Guzmán accede a un modo de vida muy diverso de aquél en que se había criado. De estas experiencias saca sus primeras lecciones, e incluso su primera astucia y su primer coraje, con los que se enfrenta al ventero del machuelo, lo denuncia a la justicia y hasta consigue salir él libre y que al otro lo lleven preso.

A partir de este momento, y en una crónica que el narrador enhebra día a día, de domingo a domingo, y casi de hora en hora, la vida se hace camino, y sus etapas ventas, y entre una y otra va encontrando un tropel de gentes del camino, arrieros, clérigos, soldados, y en los lugares por los que pasa a alguaciles, escribanos, corchetes, y de una a otra asnos y más asnos, y algún mulo, y en todas partes trifulcas, reyertas, regateos, y trampas, y robos, y estafas. Es en la venta de Cazalla donde Guzmán, para sobrevivir, se hace "mozo de ventero, que es peor que de ciego" (p.257) y allí aprende todo tipo de trucos para estafar a los pasajeros en el pienso de las cabalgaduras, en el yantar de los viajeros, y de allí sale para unirse a la legión de niños de su edad que vagan por los caminos, sobreviviendo como pueden. Cuando finalmente Guzmán llegue a Madrid su formación como pícaro anda ya muy avanzada, y quienes pudieran acogerlo lo perciben así, de manera que a Guzmán no le quedará otra que dejarse llevar en esa dirección: "Cuando llegué a Madrid [...] creyeron ser algún pícaro ladronzuelo que los había de robar y acogerme./ Viéndome perdido, comencé a tratar el oficio de la florida picardía" (p. 258).

M. Joly (1982), en un trabajo muy citado y que obtiene sus mejores resultados en su aplicación al Guzmán de Alfarache, estudió la tradición europea de la burla en conexión con la imagen de ventas y caminos que ofrecían el folklore, la literatura de viajes y algunos textos literarios relevantes. De todos estos testimonios emanaba una casi universal mala reputación de ventas y venteros que venía a reflejarse en el refranero, de la que daban cuenta experiencias de viaje como las de Nicolás Popielovo, Sebastian Münster, Andrea Navagero o el Doctor Laguna, o cartas y coloquios de humanistas como Erasmo de Rotterdam y Nicolás Clénard, o textos más elaboradamente literarios como los de Antonio de Guevara o el mismo Alemán. A menudo, y sobre todo en los testimonios más literarios, esta imagen negativa se asocia- 
ba a un propósito reformador, como es el caso de Alemán, y a la utilización del estado de caminos y posadas como referencia para medir el grado de barbarie o de civilización de las naciones por las que los viajeros atravesaban. Lo cierto es que la Primera parte de Guzmán de Alfarache transmite con fidelidad esa mal reputada imagen que, por otra parte, contribuye a fijar. Hace suya, por ejemplo, la constelación nuclear de personajes de esa tradición, conformada por los estereotipos del ventero, la ventera, el mozo y la moza de mesón. En este estereotipo el ventero encarna el refrán "mudarás de mesón, pero no de ladrón", a menudo tiene un pasado de bandolero y, con el paso de los años, ha venido a retirarse en el aislamiento de una venta ${ }^{12}$, a modo de nuevo ermitaño, pese a lo cual, y por una curiosa paradoja, suele ser cuadrillero de la Santa Hermandad en las ventas rurales, o relacionarse con alguaciles en las urbanas. Guzmán de Alfarache certifica ambos casos: "la palabra del ventero es una sentencia definitiva: no hay a quien suplicar, sino a la bolsa. Y no aprovechan bravatas, que son los más cuadrilleros y por su mal antojo siguen a un hombre callando hasta poblado y allí le probarán que quiso poner fuego a la venta y le dio palo o le forzó la mujer o la hija, sólo por hacer mal y vengarse" (p. 256), dice en un caso. Y en el otro: "lo primero podría ser encontrar con alguacil muy grande desvergonzado, que ayer fue tabernero, como su padre, si ya no tuvieron bodegón. Que si ladrón era el padre, mayor ladrón es el hijo. Compró aquella vara para comer o la trae de alquiler, como mula" (p. 613). La doble condición de ladrón y de policía, muy frecuente en los textos, se complementa con un cuadro de tropelías de catálogo: las trampas en el pienso del bestiaje, el fraude en la comida de los pasajeros, el robo de efectos personales... todas ellas muy presentes en la narración de Alemán. También la moza de mesón refleja bien el estereotipo: ella es "más que criada y menos que hija" (p. 330), escogida por un huésped que utiliza sus encantos para atraer viajeros pero a la que protege como suya para evitar que se la estropeen; es hermosa y juguetona, aunque resabiada, y Guzmán da con ella en la venta de Malagón. Por la noche, sintiendo un ruido en su aposento, Guzmán piensa que es ella que le visita y se lanza en la oscuridad a abrazarla, viniendo a abrazar una borrica que se había colado, y que le agradece el abrazo con un doloroso testarazo.

Según la estudiosa francesa la imagen negativa de la venta estaba ya implantada desde hacía tiempo en la realidad, en el léxico y en la mitología popular de la península, pero en 1599 el Guzmán "met l'utilisation littéraire du thème de l'auberge a l'ordre du jour" (p. 335). "Ce qui, néammois, donne à son intervention un caractère que l'on peut, sans exagérer, qualifier de révolutionnaire, c'est qu'il est le premier à lui assigner un rôle fonctionnel à l'intérieur du récit » (p. 335). Precisa la estudiosa que Alemán, explotando temas latentes en el folklore y la literatura de viajes hace del albergue « un lieu privilegié de tromperie" (p.335) y así lo asimilará el Quijote y se perpetuará en

12. El mesonero de Cantillana confiesa haber sido salteador de caminos antes que ventero. 
una serie de narraciones posteriores, como La pícara Justina, el Marcos de Obregón o El mesón del mundo.

El corolario podría formularse con estas exclamaciones del narrador: "¡Qué de robos, qué de tiranías, cuántas desvergüenzas, qué de maldades pasan en ventas y posadas!” (p. 256). Pero si esto es así en la Primera Parte, deja de serlo en la Segunda, aparecida en 1604, y en la que la experiencia de la venta se diversifica. En Florencia, por ejemplo, "no tardamos en llegar a una [posada] donde nos acariciaron con tanto regalo, que verdaderamente no lo sabré bien decir, como lo debo encarecer: tanta provisión, limpieza, solicitud, afabilidad y buen tratamiento. En esto estaba tan cebado, que casi me hiciera poner en olvido lo que más deseaba" (p.590). Esa excelente posada sirve de base para la exploración turística de la ciudad del Arno, guiada por el experto Sayavedra. Tampoco la posada de Bolonia pide quejas, todo al contrario, pues en ella Guzmán ganará con los naipes y la ayuda de Sayavedra una buena suma de dinero. Y menos quejas suscita todavía la posada de Alcalá de Henares, en donde encuentra a Gracia, la moza "que toda ella era una caja de donaires" (p. 818), que atrapa a Guzmán en la "amorosa pestilencia". Con ella "habíame matriculado amor en sus escuelas", y Guzmán, vencido, no tiene más remedio que abandonar los estudios universitarios que estaba a punto de acabar y el objetivo de unas oposiciones a cátedra, que bien hubiera podido conseguir "según la opinión que tuve" (p. 828), y casarse: "de bachiller en teología salté a maestro de amor profano" (p. 822). Pero la venta no es sólo el nido de esos amores, ni tampoco Gracia tiene nada que ver con la tipología de la moza de mesón. En este episodio la venta es, sobre todo, un acogedor hogar familiar. Desde el principio la ventera "tratábame como a verdadero hijo, buscando por cuantas vías podía mi regalo”, la hija y esposa era dócil y moldeable, de manera "que pude hacerla de mi voluntad", los parientes "se honraban de mí por las ventajas que me reconocían”. En suma: "mi suegra lo era mía y mi cuñada mi esclava, mi esposa me adoraba y toda la casa me servía. Nunca jamás, como aquel breve tiempo, me vi libre de cuidados" (p. 828). Pero si la venta puede ser un hogar es porque también es un medio de vida, un medio de producción que diría Marx: "Aquel mesón estaba bien acreditado" (p. 830) y la ventera "era mujer acreditada en el trato, tenía mucho y buen despacho, ganaba bien de comer" (p. 822). Todo este episodio parece replicar la imagen de las ventas servida en la Primera parte, sobre todo cuando se leen declaraciones como ésta: “Mi suegro, que haya buen siglo, aunque mesonero, era un buen hombre. Que no todos hacen sobajar las maletas ni alforjas de los huéspedes. Muchos hay que no mandan a los mozos quitar a las bestias la cebada ni a los amos les moderan la comida" (p. 829). Este es sin duda el momento en que, entre la vida del pícaro y la de maestro en Teología, Guzmán hubiera podido encontrar la vía de una vida burguesa, aquella con la que soñaba camino de Milán y que confiaba a su fiel Sayavedra: "que, si con tiento vamos, pues entendimiento no falta y entendemos algo del pilotaje, no me contento menos que con un regimiento de mi tierra y hacienda con que pasar descansadamente, antes de seis años” (p. 631). ¿Quién diría pues que la venta, escena- 
rio de trampas y engaños, lugar privilegiado de la aventura picaresca, pudiera también metamorfosearse en el escenario de una ordenada vida burguesa? Y sin embargo, como posibilidad existe, al igual que la cátedra de Alcalá: son destinos posibles, el de ventero y el de profesor, que Guzmán no puede seguir por los torcedores giros de una Fortuna siempre adversa.

En última instancia la novela de Alemán hace de la venta un lugar de significación cambiante, pero siempre ajustada a los pasos de su vida y generosamente materializada. Es cierto que la novela explora a veces los derroteros de la comedia, como en los episodios en Toledo del cortejo de damas, a las que regala y por las que es burlado, como es cierto que la venta y el camino facilitan los encuentros de gente heterogénea, y por ello mismo suscitan el relato: el de Ozmín y Daraja, por ejemplo, que cuenta un clérigo a la salida de la venta de Cantillana, o el cuentecillo de "En Malagón, en cada casa un ladrón, y en la del Alcalde hijo y padre", que cuenta un mozo a la salida de la de Malagón, que parece una historia de Bandello, con ambientación histórica incluida. Pero lo que caracteriza por encima de todo a la novela de Alemán, en su aportación a la literatura de posada, es el intenso realismo con el que entreteje el escenario material de la venta, las costumbres contemporáneas, y las experiencias que en la duración van configurando el sentido de la vida del pícaro. Hasta Mateo Alemán nadie lo había hecho. Si se comparan con su representación las distintas representaciones de posada que hasta aquí se han evocado, todas ellas resultan mucho más librescas y están elaboradas con un grado mucho más elevado de licencia imaginaria y de libertad ficcional que la de Alemán, reconducida a un estatuto referencial y verosímil de la representación.

\section{La ILUStre fregona. Novela versus Comedia.}

La ilustre fregona, publicada en 1613 y probablemente escrita entre 1606 y 1613, es según la mayoría de los estudiosos una de las más tardías novelas ejemplares. Para cuando fue escrita ya Lope había hecho representar El mesón de la corte ${ }^{13}$, y más que probablemente La noche toledana, vinculada a acontecimientos de 1605. Había sido constituida, por tanto, una fórmula de comedia urbana, de costumbres contemporáneas, centrada en un escenario casi exclusivo de mesón de ciudad. Cervantes adoptará para su novela la traza básica de la intriga en la fórmula de Lope, una traza consistente en la reducción del flujo libre de la vida a un único escenario y su entorno, una ciudad en ebullición, como Toledo ${ }^{14}$, y en una plantilla básica de personajes, de la que aprovecha fundamentalmente a cuatro. Por un lado el mesonero, aquí honorable, jo-

13. Cuya fecha más tardía sitúan Morley y BRUERTON (1968) en 1596, al tiempo que la califican como una de las obras más tempranas del poeta.

14. Bien contorneada, incluso turísticamente, tanto en la novela como en la comedia del mismo título. 
vial, dueño de un establecimiento confortable y famoso, y la mesonera, que actúa como personaje auxiliar y enteramente doméstico, en la línea de una Teresa Panza letrada. Por otro, una moza de mesón en verdad garrida, de aspecto y comportamiento distinguidos (que tiene que ver con el habitual origen noble desconocido), hasta el punto de parecer a todos una ilustre fregona, que es tratada como una hija de la casa y protegida por los mesoneros, al tiempo que admirada y deseada por todos los viajeros y aún por buena parte de la ciudad. Cervantes introduce no obstante modificaciones significativas en el prototipo: le ahorra el actuar de reclamo de los viajeros, en la calle, y la recata en el interior del mesón; elimina de entre sus pretendientes a los que podrían contaminar su figura con su grosería o su ridiculez: criados, soldados, viejos enamorados; le evita toda competencia con damas viajeras y cortesanas; la disocia netamente de todo rasgo de donaire, en beneficio de una caracterización como discreta, silenciosa, inaccesible; y finalmente le contrapone las figuras desvergonzadas de la Argüello y la Gallega, para que realcen con su contraste la pureza de Costanza. El cuarto es un falso mozo de mesón, que esconde bajo su apariencia a un joven de condición distinguida, un estudiante que por amor de la moza ha colgado sus estudios y consume en la venta los recursos que su padre pusiera a su disposición para estudiar. De las dos soluciones que Lope preveía para el falso mozo de mesón, la del estudiante y la de la dama disfrazada de varón, con funciones de donaire, Cervantes elige claramente la primera, probablemente por razones de verosimilitud. En cuanto al resto de personajes, Cervantes se regala con una mayor cuota de libertad: elimina a los que complican la intriga (damas y galanes secundarios), a los militares y también a los viejos enamorados, y abre en cambio las puertas a una colectividad popular y verosímil: mozas de mesón y mozos de mulas, aguadores, alguaciles, a los que añade al Corregidor y su hijo, un tierno e inofensivo enamorado, y a los dos caballeros graves, que resultarán los padres de los jóvenes protagonistas.

En este escenario y con este abanico de personajes Cervantes construye una acción en la que mantiene la imagen del mesón como mesón de amores y lugar de encuentros azarosos e insospechados, donde la intriga principal es de índole amorosa y se traba entre la moza falsa de mesón, la Ilustre fregona, y el mozo falso de mesón, el distinguido estudiante. Cervantes completa esta intriga con escenas entremesiles, que sin embargo explota bastante más que Lope: en el baile de la Chacona, ante las puertas del mesón, y en el entremés de "Daca la cola, asturiano". Prescinde, por otra parte, del enredo de amores disimétricos y entrecruzados, y de las escenas nocturnas de equívocos. Las transgresiones son mínimas o se han neutralizado: ni hay inversión en las relaciones entre padres e hijos, ni de la jerarquía de rangos sociales, ni, por supuesto, nada parecido a las escenas de erotismo hermafrodita o de apariencia homosexual que tanto gustaban a Lope. El desenlace, con la restauración del orden que supone, es aquí bastante más severo y rotundo: nada de alguaciles más o menos graciosos, ni de viejos verdes. Los padres, honorables y graves, ponen una parte de la solución, el Corregidor, suprema autoridad local, la otra. Los desórdenes que sin embargo se reintegran no son menores que en las co- 
medias de Lope y alcanzan a los propios padres: D. Diego de Carriazo cometió en el pasado una violación; su hijo, Diego de Carriazo, es un aventurero impenitente, que por dos veces ha escapado de casa para dedicarse a la vida picaresca o a emplearse como mozo de mesón y como aguador, y que ha sido preso en dos ocasiones por la justicia; el otro joven, D. Tomás de Avendaño, dejó sus estudios en la Universidad de Salamanca para reconvertirse en mozo de mesón y cortejar a una fregona con la intención de casarse con ella. Del más culpable de estos desórdenes al más leve, todos encontrarán su solución en el desenlace.

Hasta aquí lo que Cervantes aprovecha de la fórmula de Lope y lo que modifica para hacerlo material suyo y de novela. Pero hay otras muchas cosas que pone Cervantes de su cosecha y que no están en las comedias de Lope, ni siquiera como posibles. Algunas de ellas se deben al género escogido. Así es obvio que la fórmula novelesca que Cervantes explora en sus albores, aquí como en el Quijote de 1605, permite jugar con las intervenciones del narrador, la exhibición de una geografía urbana precisa, o la complacencia en la evocación de lugares, oficios, costumbres, y tipos que confieren a la novela su extraordinaria riqueza referencial, muy por encima de la que es propia de la comedia. En la generosa -en detalles - caracterización del medio se cuelan a veces datos inquietantemente críticos: la amenaza siempre presente de la Inquisición, la dureza de la represión de los delincuentes en Sevilla, el poder discrecional sobre la vida de los ciudadanos del Corregidor de Toledo, la corrupción de la justicia, del alguacil a los jueces...

Pero buena parte de las aportaciones de Cervantes tienen poco que ver con la opción del género novelesco. Así ocurre con las que se refieren al universo representado, a la materia prima de la inventio. Cervantes añade toda una dimensión que no está en Lope, pero sí en Alemán y en su propia y anterior Rinconete y Cortadillo, la dimensión picaresca, presente en los prolegómenos de la novela (con la primera fuga de Carriazo), en el análisis de la inadaptación de los dos jóvenes al rol social que les ha sido asignado, en la segunda fuga con la burla de su tutor- y su escapada a Toledo, o en episodios como el de la pelea de Carriazo con el aguador y en aquel otro del "Daca la cola, asturiano". En esta invención de un universo social apicarado tiene una gran relevancia el papel asignado a la Argüello y a las mozas gallegas, portavoces de una forma de entender el amor nada platónica ni sofisticada, como lo tiene el del mozo de mulas Barrabás. No obstante, esta considerable ampliación del universo del mesón que Cervantes aporta, no es inocua, ni se hace sin selección. Sobre ella opera una dispositio que busca siempre el contraste entre la realidad más desnudamente empírica y su contraversión más idealizada, Costanza será objeto de un cuidadoso trabajo de descontaminación de la escoria de lo real, de una idealización que cobra todo su relieve cuando se la contrasta con la Argüello y la Gallega. Pero también los jóvenes, semejantes en muchos aspectos, serán contrapuestos en lo esencial: Avendaño es proyectado hacia el amor platónico mientras que Carriazo lo es hacia la aventura social. También la música y la voz poco menos que celestiales del hijo del Corregidor serán confrontadas, a 
la vuelta de unas pocas líneas, con el grosero baile de la Chacona y con la voz de Barrabás, mozo de mulas. Y así sucesivamente: Cervantes no incorpora sin más el universo de la picaresca, como aparecía en Mateo Alemán, lo incorpora replicándolo, como es bien sabido, lo incorpora asumiéndolo en una visión más relativizadora y dialéctica, también más compleja, pero sin duda más idealista.

La imagen resultante del universo de mesón recupera la dimensión que tuvo en su origen, el del lugar de los relatos. Aquí un relato oral, contado por el Huésped y escuchado por el Corregidor. Y también ratifica la que le había proporcionado la comedia: la del momento en que se conducen a su desenlace historias anteriores, comenzadas en otro lugar, y que arrastraban consigo un drama humano sin resolver: si en las comedias se trata de una seducción seguida de un abandono, aquí el registro es más duro, pues trata nada menos que de una violación, y su resolución se aplaza durante toda una vida. Cuando finalmente llega, la principal víctima ya ha muerto, y para ella no hay compensación posible.

Un último aspecto novedoso aporta Cervantes en su novela ejemplar. Aunque sea sólo de un modo embrionario, sobre todo si lo comparamos con el Quijote de 1605. Me refiero a la lectura e interpretación de un texto literario por los personajes de la novela. Aquí son el mesonero y la mesonera quienes leen y comentan los versos que Tomás de Avendaño ha escrito en el cuaderno de cuentas de la cebada y de la paja, y como el Cura y el Barbero, aunque en un nivel diferente, su lectura lo es en clave de vida, que interpreta la escritura a partir de las vivencias que expresan y de las consecuencias que sobre la vida del mesón pueden llegar a tener esas vivencias.

La comedia La Ilustre fregona y amante al uso, que se publicó póstumamente en la Veintiuna Parte perfecta de las Comedias del Fénix de España, Frey Lope Félix de Vega Carpio, en Zaragoza, por Pedro Verges, en 1641, puede que no sea de Lope. Así lo creyeron J. Oliver Asín (1928) y su editor moderno, E. Cotarelo. Morley y Bruerton, por su parte, diagnostican: "No creemos que la comedia sea de Lope" (1968, p. 481). Lo que es evidente es que se trata de una versión muy libre de la novela de Cervantes, y que deriva de ella tanto como tiene en cuenta la fórmula de las comedias de mesón de Lope. Una consideración sintética de la relación entre la novela y la comedia ratifica de manera bastante contundente cuanto se ha dicho sobre las transformaciones que Cervantes introduce en la fórmula de Lope, precisamente porque la comedia trata de restituir los procedimientos característicos de esa fórmula.

El autor adapta el núcleo del argumento cervantino, expulsa de él toda la materia picaresca, y recupera en cambio una intriga secundaria, con nuevos galanes y damas y con un criado gracioso. El Corregidor ahora no sólo tendrá un hijo, sino también una hija, doña Clara, de quien se enamora Carriazo, otro que se queda en Toledo para cortejar a su dama. Con esta simple operación Carriazo pierde su dimensión de pícaro y se reconvierte en galán de comedia. En cuanto a Costanza, el dramaturgo la hará objeto de la rivalidad de dos galanes, el hijo del Corregidor, don Pedro, y don Tomás de 
Avendaño. A los dos caballeros burgaleses les sirve de criado el gracioso Pepín. Otro criado, Antonio, viene a evitar que el galán Don Pedro quede cojo y sin servicio. Por su parte Costanza recibirá la compañía constante de Inés. Añadanle ustedes billetes dispuestos y extraviados o rotos, historias de cambio de identidad para huir de una muerte cometida, un retrato de dama que sirve para enamorar a distancia y otro que provoca un equívoco, dobles enmascaramientos del gracioso, un violento encuentro de capa y espada, y otros motivos típicos de la comedia, bastante torpemente usados, y tendrán el resultado. Entre las mutaciones que sufre el argumento cervantino quizá las más decisivas son las que afectan a Costanza, que pasa a desempeñar un papel mucho más activo, de dama interesada en llevar a buen término sus amores, y a Pepín, el "amante al uso" del subtítulo de la obra, que es quien conduce la trama de engaños e invenciones.

\section{Don QuiJote DE LA MANCha: La alianZa ENTRE VIDA Y LITERATURA.}

Con el Quijote llegamos al fin de nuestro viaje, pero la venta que nos acoge es todo lo contrario de una estación terminal, se abre a un horizonte dilatado sobre el que se contempla la diversidad de la vida pero también su renovada y múltiple alianza con la literatura.

Apenas sale de su casa don Quijote y ya tropieza con una venta, le ocurre como a Guzmán: su primer encuentro con el mundo, su primera aventura será en su primera venta, la venta es el lugar de iniciación tanto de la caballería como de la picaresca.

Antes, don Quijote ya ha mostrado una excelente capacidad de improvisar soluciones prácticas para las dificultades de llevar a la práctica su quimera. Le hemos visto resolver con industria los problemas de reunir un armamento adecuado, y ahora le veremos resolver el asalto de un pensamiento terrible: mal podrá ejercer la caballería si no ha sido armado caballero. Y como ya hizo con las armas, vuelve a hacer ahora, improvisando rápidamente: "propuso de hacerse armar caballero del primero que topase, a imitación de otros muchos que así lo hicieron, según él había leído en los libros que tal le tenían"15. Lo importante es conocer el código, después uno lo pone en práctica según y cómo, no hay que ser demasiado perfeccionista, y don Quijote es, desde el principio, y aunque no se haya caído en la cuenta muchas veces, un personaje casi tan posibilista como quimérico, o al menos posibilista dentro de lo que le permite la quimera.

Esta primera venta que encuentra el caballero es de categoría semejante a la que encuentra el pícaro, aunque más rural y apartada, sin ningún regalo ni

15. Cito por la edición del Instituto Cervantes (1998), vol. I, pp. 45-46. Todas las citas remiten a esta edición. 
comodidad. Por no haber no hay ni camas, y de comer sólo tienen truchuelas, que en Castilla llaman abadejo, y que le sirven mal remojado y peor cocido. La sordidez de la venta está a tono con quienes hacen allí parada: arrieros y mozas de partido, un castrador de puercos, un porquero... El ventero es gordo y pacífico pero tiene un pasado turbulento, de ladrón y de estudiantado paje. Todo evoca aquí el ambiente de la picaresca española, incluso la manera que improvisa el ventero de hacerle beber el vino a don Quijote con una caña metida por la celada, que trae a la memoria cómo lo bebía por trampa Lázaro de Tormes ${ }^{16}$.

No se podría haber escogido lugar de mayor dificultad para estrenar sus quiméricas andanzas, y sin embargo don Quijote lo afronta con un intento radical de tergiversación del lugar real, tratando de reconvertirlo en lugar quimérico: la venta es un castillo, las putas elegantes damas, el cuerno del porquero una trompeta de bienvenida, y las truchuelas una suculenta trucha. El conflicto entre quimera y realidad está servido, y el desencuentro lingüístico es patente: aquí como en la venta de Juan Palomeque, don Quijote se esfuerza en hablar como se habla en los libros de caballerías, pero las rameras no le entienden y su figura les provoca risa, que a su vez provoca el enojo del caballero. Las formas de la picaresca frente a las formas de la caballería, un conflicto de lenguajes, de modos de vida, de ideologías, y también de poéticas ${ }^{17}$. Cervantes lo escenifica con toda nitidez durante la vela de armas en el patio, transformado en campo de batalla. Pero al mismo tiempo le proporciona una salida que es todo un manifiesto literario. Entre el castillo encantado en el que quiere situarse don Quijote y la venta picaresca en que los arrieros quieren dar de beber a sus mulas hay una posibilidad de entendimiento. Lo facilitan el ventero, con su sentido socarrón del humor, y don Quijote con su posibilismo. Los dos se entienden citando el romancero, pero además el ventero es lector de libros de caballerías y puede improvisar una versión caballeresca para su propia biografía, traduciendo su itinerario picaresco por los lugares más famosos del hampa de toda España en un ejercicio de andante caballería, o adaptando su venta a las apariencias de un castillo, aunque sea sin capilla ${ }^{18}$. Cuando vuelen las pedradas, los golpes y los improperios, será el ventero quien mediará para evitar mayores destrozos, pero en lugar de deshacer el entendimiento volverá a adaptarlo, a fin de cuentas lo esencial de la investidura son una buena pescozada y un espaldarazo. El ventero está incluso dispuesto a renunciar al cobro de su cuenta, que perdona al caballero con tal de verlo fuera de allí. Claro que don Quijote también pone de su parte. No es fácil para un iluminado aceptar que le reduzcan la vela de armas de toda una noche a tan sólo dos horas, que el libro de ceremonias de la investidura sea el libro de

16. Episodio que debió impresionar a Cervantes, pues ya lo evoca en las páginas preliminares de la novela, en el poema del Donoso Poeta Entreverado, dedicado a Sancho Panza y Rocinante (p. 29).

17. Véanse los comentarios de M.Carmen MARTín PINA sobre el encuentro de ventero y caballero como encuentro entre dos géneros de ficción y sus poéticas, en F. Rico ed (1998), vol. comp. p. 22.

18. "Un chateau sans chapelle", un castillo sin espíritu, como tal lo analiza N. Ly (1988), pp. 5-92. 
cuentas de la paja y la cebada ${ }^{19}$, o que las damas del castillo se llamen la Tolosa y la Molinera sin otra condición que anteponerse el doña. Pero aún pone más don Quijote, pone su conformidad con algunos de los consejos prácticos del ventero sobre las prevenciones "que un caballero había de llevar consigo, especial la de los dineros y camisas", por lo que "determinó volver a su casa y acomodarse de todo, y de un escudero" (p.62). Don Quijote sale pues de la venta dispuesto a rectificar, a comenzar de nuevo, a aceptar una parte de las condiciones que la realidad de la venta le ha impuesto, a asumir algunas de las enseñanzas recibidas en ella. Se suele aducir por los estudiosos, a partir de una observación de Martín de Riquer (1956), que la investidura del caballero carece de validez porque la recibe con escarnio, y no les faltaría la razón si don Quijote hubiera tenido que ejercer de caballero en Argamasilla del Alba o en las lagunas de Ruidera, pero donde tiene que ejercer es en las páginas de un libro y en ellas a mí me gusta ver lo que puede ver un lector de novelas, y no un curioso de la historia: que la investidura como caballero de don Quijote es fruto de un pacto en que ambas partes rebajan sus exigencias, y que ese pacto resulta efectivo, pues a partir de él don Quijote se siente efectivamente caballero. Si la comparamos con la de Guzmán, su iniciación a la vida no tiene un carácter tan repulsivo ni es un indicio tan funesto, resulta incluso aceptable, al menos para quien la experimenta. Y de la misma forma y por las mismas razones, el encuentro conflictivo entre la poética de la novela picaresca y la de los libros de caballerías se resuelve como una escaramuza sin victoria ni derrota decisivas, dentro de unas hostilidades que se extenderán a todo lo largo de la novela y en las que, desde el principio, se vislumbra una paz aceptable por ambas partes.

Ha escrito M. Joly (1982, p. P. 337) que el hallazgo genial de Mateo Alemán consistió en descubrir, gracias a la venta, una mutación realista del castillo encantado de los cuentos fantásticos, pero El Quijote, al preservar el doble aspecto de venta y de castillo, nos muestra a un Cervantes más dotado como teórico de la literatura que todos sus predecesores o contemporáneos, y muestra que es el único que ha sabido apreciar en su justa medida el alcance de la innovación de Mateo Alemán.

Todo este primer episodio de la venta se sitúa en una perspectiva verosímil, de análisis espaciotemporal rigurosamente realista: es un viernes del mes de julio, antes de salir el sol, cuando don Quijote sale de su casa, y cabalga durante todo un día de bochorno por los campos de Montiel hasta que al atardecer se dirige a una venta, que se materializa ante el lector con los signos de una realidad perfectamente reconocible. Pero su realismo y su verosimilitud son más complejos que los que maneja Mateo Alemán, porque forman equipo con un sorprendente juego literario, que se despliega suntuosamente desde el prin-

19. Es un motivo simbólico que gustaba a Cervantes. En La Ilustre fregona también los versos de idealizado amor de Tomás de Avendaño se escriben sobre el prosaico libro de cuentas de la paja y la cebada, para alimentación de cabalgaduras. 
cipio mismo de la novela. En este juego la escritura se alimenta de códigos previos, especialmente el del libro de caballerías, aunque también los de la novela picaresca, el paso o entremés, la narración pastoril o la sentimental: es una escritura segunda, una metaescritura. La secuencia de la vela de armas por realista y entremesil que parezca, no deja de ser un relato caballeresco, aunque burlesco y paródico, y sus fuentes han podido ser reconstruidas (Martín, 1998, pp. 23-24). La parodia supone un juego de la escritura sobre la escritura, y por consiguiente una manifestación de autoconciencia literaria a menudo armada con intención de manifiesto, como ocurre en este caso. Pero la autoconciencia no se reduce a la utilización de los códigos de otros géneros o a la parodia de uno de ellos en su conjunto, está presente en una articulación sutil y compleja de los niveles de enunciación que acaban por convocar al propio acto de la escritura al interior de la representación. De forma semejante a Las Meninas, como ya señaló E. C. Riley (1966, pp. 86-87) y estudió fascinado M. Foucault (1966, caps. I y III), la representación representa a quien la representa, lo representado adquiere a su vez capacidad de representar, Velázquez está dentro y fuera de su mundo, como Cervantes. Déjenme parafrasear de forma inevitablemente personal un juego bien conocido, según el cual Cervantes cuenta que el traductor cuenta lo que Cide Hamete Benengeli cuenta que los sabios encantadores o cronistas cuentan lo que don Quijote dice o hace. Habría que añadir los Anales de la Mancha y alguna otra instancia, como la de los autores que disienten sobre cuál fue la primera aventura del caballero (p. 48), o la de los propios personajes que cuentan o leen en voz alta diversas historias, que son bastantes. Pero lo que aparece de forma decisiva en este episodio es que toda esta jerarquía de actos narrativos que conduce desde el Autor hasta el Personaje, puede ser invertida. Ocurre cuando don Quijote, hablando consigo mismo, va diciendo: “¿Quién duda sino que en los venideros tiempos, cuando salga a luz la verdadera historia de mis famosos hechos, que el sabio que la escribiere no ponga, cuando llegue a contar esta mi primera salida tan de mañana, desta manera: "Apenas había el rubicundo Apolo..."”. Y efectivamente Cervantes escribe: "Apenas había el rubicundo Apolo tendido por la faz de la ancha y espaciosa tierra las doradas hebras de sus hermosos cabellos..."(p. 46). Eso supone que Cervantes cuenta lo que Cide Hamete Benengeli cuenta que el sabio cronista cuenta lo que don Quijote cuenta que Cervantes escribe. La representación es así atrapada por lo representado y el autor por su personaje y el acto de escritura por la ficción narrada. No es más que el primer asalto de un combate que tendrá muchos otros a lo largo de la novela.

Y algunos de los más espectaculares transcurren en las ventas del Quijote de 1615. En esta Segunda parte, don Quijote no confunde ya nunca las ventas con castillos, y menos después de su vencimiento en Barcelona, porque desde entonces "con más juicio discurría" (p.1202), y tampoco las ventas tienen el aspecto sórdido de la Primera parte, alguna hay incluso en la que la sensación de bienestar y holgura es patente, como la que aloja a maese Pedro (Cap. XXV), quien se ha hecho rico representando su retablo y haciendo adi- 
vinar a su mono en ventas como ésta, pagado por los viajeros. La que acoge a D. Álvaro Tarfe es "posada limpia y fresca" (cap. LXXII), con sus sargas pintadas con temas de la épica antigua. Los venteros son amables, cordiales, y a veces hasta tan fantasiosos como don Quijote, como aquél (Cap. LIX) que les ofrece de comer lo que pidan, pues tiene de todo, y después va descontando todo lo que le piden, pues de eso no tiene, hasta acabar ofreciendo lo único que tiene, dos uñas de vaca, eso sí, bien cocinadas, que harán la felicidad de Sancho. Pero lo decisivo de estas últimas ventas que acogen a don Quijote es que van a ser utilizadas como escenario de una batalla literaria, que sorprendentemente no se juega en el mundo representado sino en el mundo de la representación, donde Cervantes arremete contra el usurpador Avellaneda. A la primera de estas ventas Cervantes convoca a dos caballeros que están leyendo, aunque con críticas, el Quijote de Avellaneda. Don Quijote les aborda y y ellos le reconocen de inmediato como el verdadero, a su vez Sancho se reivindica a sí mismo frente al Sancho sucedáneo, que no se parece en nada a él, pues es comilón y simple, y nada gracioso, como reconocen todos los que han leído el libro de Avellaneda: "Sí soy [Sancho] y me precio de ello", declara solemnemente. Don Quijote hojea el libro del usurpador y hace sus críticas, pero lo deja pronto, por no seguirle el juego. Los caballeros lectores, indignados también ellos, niegan el derecho a cualquiera "que fuese osado a tratar de las cosas del gran don Quijote, si no fuese Cide Hamete, su primer autor" (p.1114). Informado don Quijote que su suplantador estuvo en Zaragoza, decide rectificar su ruta y no dirigirse a esa ciudad, sino a Barcelona, por desmentir de forma rotunda a Avellaneda y que nadie pueda decir o creer que el verdadero Don Quijote estuvo alguna vez en Zaragoza.

Pero en la tercera y última venta que visitará don Quijote, en el antepenúltimo capítulo de la novela, Cervantes va más lejos. Hasta ahora había utilizado a personajes lectores para tratar de temas literarios, aunque fuese sobre su propia obra: el cura, el barbero, el ventero, el canónigo de la Primera Parte, Sansón Carrasco o estos dos caballeros, en la Segunda. Pero ahora su osadía imaginativa lleva hasta contestar a Avellaneda con sus propias armas, sacando de su libro a uno de los principales personajes, don Alvaro Tarfe, y trayéndolo a sus propias páginas para carearlo con don Quijote. La escena es bien conocida y no me detendré en ella. En esencia don Quijote y Sancho denuncian la suplantación de sus identidades por Avellaneda y reivindican las propias: "El verdadero Sancho Panza soy yo", declara Sancho, y su amo: "yo soy Don Quijote de la Mancha, el mismo que dice la fama, y no ese desventurado que ha querido usurpar mi nombre y honrarse con mis pensamientos." El momento es de una solemnidad extraordinaria. Nada queda aquí de la parodia de los libros de caballería. Don Álvaro reconoce con mucho gusto sus derechos a la autenticidad, y firma allí mismo una declaración en este preciso sentido ante el alcalde del pueblo y un escribano. El suplantado toma las armas del suplantador para contestarle, pero las armas son elementos de la ficción y la batalla en cambio se juega en la realidad. Cervantes acusa a Avellaneda valiéndose de don Quijote y de D. Álvaro Tarfe como instrumentos. Son los pode- 
res de la ficción y Cervantes muestra de una manera fulgurante que con esos poderes se puede intervenir en la realidad. Todavía en el último capítulo Cervantes, por boca de Cide Hamete Benengeli, utiliza las últimas líneas de su novela, las que por su posición gozan de más autoridad, no sólo para volver a atacar a Avellaneda por cuestión de principios, sino para advertirle, amenazarle, tratar de impedir a toda costa lo que sin duda Cervantes más temía, que Avellaneda replicara con una nueva continuación: le advertirás, dice Hamete a su pluma, "que deje reposar en la sepultura los cansados y ya podridos huesos de don Quijote, y no le quiera llevar, contra todos los fueros de la muerte, a Castilla la Vieja, haciéndole salir de la fuesa, donde real y verdaderamente yace tendido de largo a largo, imposibilitado de hacer tercera jornada y salida nueva" (p. 1223). Cuando uno escucha estas palabras no puede evitar sospechar si acaso Cervantes decidió matar a don Quijote, como Unamuno a Augusto Pérez, en lugar de reconvertirlo en pastor, como tenían tratado Sancho y él, para evitar que otro autor, encontrándoselo vivo, lo hiciera salir de nuevo.

Cuando en la segunda mitad de los setenta comienza a manejarse en los Estados Unidos el concepto de Metaficción ${ }^{20}$ (Robert Alter, Brian Stonehill, Lynda Hutcheon, Patricia Waugh), el de Self-Begetting Novel (Steven Kellman), el de Surfiction (Raymond Federman), el de Reflexive Novel (Michael Boyd) u otros similares, que asimilarán primero al concepto de autoconciencia literaria, y en muchos casos a una poética propia de la postmodernidad (L. Hutcheon), la tendencia más generalizada es a interpretar esta autoconciencia literaria como un instrumento al servicio de la emancipación de la literatura de toda vinculación con la realidad: al promover en el lector la conciencia de artificio y de ficcionalidad de los procedimientos novelísticos colapsan la ilusión de realidad y desconectan el texto de la experiencia vivida y de las referencias históricas, puramente ilusorias. En algunos de estos teóricos se trata de procedimientos concretos, aislables, que la literatura puede o no utilizar según el contexto y el momento histórico, y de forma parcial o sistemática, en otros en cambio, y en ello vienen a coincidir con la teoría literaria postestructuralista de un Roland Barthes o de un Michel Foucault, responden a un movimiento irreversible de la estética de la Modernidad, cada vez más agudizado: el que a partir de la tesis de la cárcel del lenguaje proclama gozosamente que la literatura sólo puede hablar de la literatura y que el lenguaje y la realidad son universos no conmensurables ${ }^{21}$. A mi modo de ver, el Don Quijote de Cervantes es una formidable refutación de esta última tesis, refutación que se reproduce en muchas de las novelas más innovadoras al filo del milenio, y que he estudiado en otra parte (Oleza, 1996). En todas ellas, como en Don Quijote, la ficción es el campo de batalla en el que se dirimen los conflictos de lo real.

20. A partir del libro de Robert Alter, Partial Magic. The Novel as a Self-Conscious Genre (1975). Para una panorámica sobre el tema y los ensayos aquí evocados, vid. F. G. OREJAS (2003), cap. I.2.

21. Vuelven a plantearse el tema respecto a Don Quijote, Ana Ma . Dotras (1994) o el citado F. G. OREJAS (2003), y desde un punto de vista ligeramente diferente, aunque sin detenerse en el Quijote, Patricia CIFRE (2003). 
La segunda venta que acoge a don Quijote, en la Primera parte, la de Juan Palomeque, se encuentra en las estribaciones de Sierra Morena, a dos jornadas de camino de la aldea del caballero (p. 436), y su estancia en ella se reparte en dos visitas. En la primera se demora Cervantes dos capítulos (XVI y XVII) para contarnos lo sucedido de una tarde a la mañana siguiente, y sobre todo a lo largo de una ajetreada noche; en la segunda se demora mucho más, nada menos que quince capítulos (del XXXII al XLVI) para contar no mucho tiempo más, apenas dos días (p. 536), aunque sí muchas más cosas. En conjunto, don Quijote y Sancho pasan en la venta diecinueve de los cincuenta y dos capítulos del Quijote de 1605, es decir, un tercio largo de la novela, lo que expresa bien claramente la importancia que a la venta le concede su autor como ámbito narrativo.

En esta venta Cervantes acata muy poco el núcleo de personajes que la tradición y la picaresca han establecido, como ya reconociera M. Joly (1982), especialmente en lo que se refiere al personaje de Maritornes, una versión muy heterodoxa de la moza de mesón, aunque su fealdad no le exime de mostrarse libidinosa con los pasajeros, ni su malicia de gastarles pesadas bromas, pero es también sentimental y compasiva con Sancho, a quien da de beber vino pagado de su bolsillo después del manteamiento, como buena samaritana. En cuanto al ventero, Juan Palomeque, que es asimismo cuadrillero de la Santa Hermandad, como mandan los cánones, no es gordo ni pacífico, como el de la primera venta, sino irascible, pronto al mojicón, y muy celoso de sus cobros, hasta el punto de pelear a brazo partido con dos huéspedes que quieren marcharse sin pagar, de quedarse con las alforjas de Sancho como prenda del pago que no hace don Quijote, y de espetarle a éste, cuando le viene con la excusa de que los caballeros andantes no pagan: "Dejémonos de cuentos ni de caballerías, que yo no tengo cuenta con otra cosa que con cobrar mi hacienda." (p. 183). Y sin embargo es un lector entusiasta de los libros de caballerías, que escucha en el tiempo de la siega en lecturas colectivas. Y guarda como un tesoro la maleta que se dejó olvidada un viajero y que contiene algunas de ellas, así como otras de Cervantes, pues "de mí sé decir que [...] querría estar oyéndolos noches y días" (p.369). De hecho, tres de los residentes en la venta son lectores adictos de los libros de caballerías, aunque los leen con gusto diferente. Al ventero le apasionan los golpes y las batallas, a Maritornes las escenas amorosas de achuchones, a la hija las lamentaciones de los caballeros en ausencia de sus amadas. Pero ninguno de ellos confunde la literatura con la vida: esos libros "verdaderamente me han dado la vida", confiesa el ventero (p. 369), pero "no seré yo tan loco que me haga caballero andante, que bien veo que ahora no se usa lo que se usaba en aquel tiempo, cuando se dice que andaban por el mundo esos famosos caballeros" (p. 374).

Si estos son los habitantes de la venta, los que por ella pasan en esos pocos días son legión, pero una legión que recorre la escala social casi entera: allí se reúnen nobles como don Fernando, caballeros como don Luis, damas de mayor o menor condición como Lucinda y Dorotea, incluso una dama mora, doncellas como doña Clara, un Oidor, servidores cualificados y lacayos, un 
cura, un capitán, dos barberos, un grupo de cuadrilleros, un arriero rico y otros menos, perailes, agujeros y hasta vecinos de la Heria de Sevilla, mozos en fin de la picaresca. Parece como si Cervantes recuperara la intención de Chaucer de convocar en un lugar de reunión a personajes de distintas edades, sexos, procedencias geográficas, y condiciones sociales, y repartir a cada uno su turno de palabra, aunque aquí viajan con propósitos muy diferentes y saben que al despedirse de la venta se despedirán también entre ellos para seguir destinos divergentes. La venta deviene entonces un abreviado teatro o mercado de la sociedad contemporánea.

Las características materiales de esta segunda venta no son muy dispares de las de la primera o de las primeras del Guzmán de Alfarache. Dorotea advierte a la recién llegada Zoraida: "No os dé mucha pena, señora mía, la incomodidad de regalo que aquí falta, pues es propio de ventas no hallarse en ellas" (440), en verdad son palabras muy cortas para calificar el alojamiento que les es proporcionado: las cuatro damas se meten en un camaranchón que es un antiguo pajar, mientras los caballeros se apretujan en parte de la estrecha cama del ventero ( se supone que la otra parte la ocuparían el ventero, su mujer y su hija) y en la mitad de la que el Oidor traía consigo (p. 495). A uno le queda la curiosidad de saber sobre qué o quién va a parar Maritornes, y comienza a sospechar que los hermanos Marx leyeron esta escena para hacer la suya del camarote en A Night at the Opera.

En esta venta de Juan Palomeque, y especialmente en la segunda estancia, aquél propósito inicial de Cervantes al escribir su libro, y que todavía evoca Cide Hamete en las últimas frases del mismo ("no ha sido otro mi deseo que poner en aborrecimiento de los hombres las fingidas y disparatadas historias de los libros de caballerías") parece definitivamente desbordado por una escritura de estrategias más complejas y diversificadas.

Si se trata de abarcar este despliegue estratégico en unas pocas líneas, no habrá más remedio que confesar la admiración con que una tal variedad de direcciones nos sobrecoge, no comparable a nada de lo que se ha leído en nuestro viaje a través de la literatura de mesón. Convocando a mi discurso a las distintas ventas, he distinguido en principio cuatro grandes ejes de narración: el de la acción, el de la controversia, el de la audiencia y el de la reflexividad, éste último ya tratado. Pero cada uno de estos ejes se diversifica a su vez.

Como narración de acciones en el presente la novela aborda por un lado las de don Quijote y Sancho, y por el otro las del resto de personajes. Entre las de don Quijote las hay eróticas (la visita nocturna de Maritornes y la burla de la mano y la ventana), las hay de orden público (el litigio con los cuadrilleros de la Santa Hermandad), y las más son propiamente quiméricas (la investidura, la lucha con los cueros de vino y la disputa del yelmo de Mambrino). Entre las del resto de los personajes, todas de signo amoroso, hay algunas que empezadas mucho antes llegan a la venta a encontrar su desenlace (la de los amores de Dorotea y don Fernando y de Lucinda y Cardenio), y otras que están en 
pleno desarrollo, y que quedan abiertas hacia el futuro (la del Oidor, D ${ }^{\text {a }}$ Clara y don Luis).

Como narración de controversias asistimos a dos muy definidas: el debate sobre los libros de caballerías y los de historia, y el discurso de don Quijote sobre las armas y las letras, pero hay una tercera que es a la vez debate y acción, la del yelmo de Mambrino.

En audiencia somos espectadores de tres historias, dos de ellas en la venta de Juan Palomeque y la otra en la Segunda parte, pero las tres presentan situaciones de audiencia distintas: una es la lectura colectiva de un relato literario, El curioso impertinente; otra es la audición de un relato oral, la del Capitán cautivo; la tercera es una representación de títeres, el retablo de Maese Pedro.

Finalmente, y en el eje de la reflexividad, dos son los relatos completos, ya citados: el de los dos caballeros lectores y el de don Álvaro Tarfe.

No es éste el lugar de desmenuzar historia por historia, pero sí el de evocar que estas historias responden a las estrategias con que Cervantes se plantea muchos de los temas fundamentales del Quijote: la naturaleza de la verdad en su referencia a la realidad, a la subjetividad y al universo de las ideas puras (en el yelmo de Mambrino), o la de la libertad (en las historias del Cautivo y de don Luis), o las conflictivas relaciones entre ficción e historia, o entre autobiografía y ficción (ambas en la del Cautivo), entre literatura y vida (en el debate sobre los libros de caballerías), entre utopía y experiencia práctica (en la investidura, en El curioso impertinente), entre utopía y orden legal (en la de los Cuadrilleros), entre el amor y las conveniencias sociales (en todas las historias amorosas), entre el amor puro y el deseo (en las historias eróticas), entre la contemplación y la acción (en el discurso), entre el plagio y el derecho a la propiedad de la creación artística (en las de los caballeros lectores y en la de D. Álvaro Tarfe).

A su vez, todas estas historias actuadas, debatidas, contadas o vueltas sobre sí mismas, mantienen sutiles relaciones entre ellas, además de pisar sobre un mismo escenario. El discurso de don Quijote en torno a la superioridad moral del ejercicio de las armas sobre el de las letras sirve de prólogo a la historia del Capitán Cautivo, que encuentra su epílogo y a la vez su desenlace en la del Oidor. La historia de Dorotea y de D. Fernando se engarza con la del Cautivo a través de un personaje común, el hermano de D. Fernando y compañero de cautiverio del Capitán, pero también con las del caballero de la Triste Figura por medio de la invención de la Reina Micomicona, y así sucesivamente.

La sutileza y la pluralidad de las relaciones entre los múltiples relatos impiden vincularlos en una estructura rígida, como la de las novelle enmarcadas de los Canterbury Tales o del Decamerone, pero tampoco los disgrega a la manera del Morgante Maggiore o del Orlando furioso. Esa vasta audición a la que el lector se ve invitado no genera una dispersión del sentido, su pluralidad no hace naufragar su coherencia. Las muchas voces y las muchas historias no siempre tienen como resultado el tumulto o la diseminación, de la misma forma que los muchos instrumentos musicales entremezclados pueden no dar por resultado la cacofonía sino, si se combinan en orquesta, una sinfonía. 
Observada en su conjunto esta sinfonía sigue una línea melódica de incesante sucesión de novedades, que van acumulando sobre la escena personajes que, en la venta de Juan Palomeque, no se retiran en ningún momento de la misma, sino que aguardan a la asamblea final de todos los actores, previa a su despedida. Es una estructura que ya hemos visto en la comedia. Al principio son seis los viajeros que llegan a esa venta, en el capítulo XXXII, y allí se estanca la acción en una tregua de demorada reflexión y de disfrute de la lectura, se debate sobre los libros de caballerías y se lee El curioso impertinente, pero la lectura no llega a su fin, porque es interrumpida por los gritos de Sancho que piden ayuda para su amo, que anda a cuchilladas con un gigante. Al acudir todos se encuentran a don Quijote en medio de un mar de vino, entre cueros degollados. Apenas se han recuperado de la conmoción, y escuchado el final de El curioso impertinente, cuando ya ven llegar a cuatro hombres a caballo, con lanzas y adargas, y todos con antifaces negros, y junto con ellos una mujer vestida de blanco, con el rostro también cubierto, y unos mozos a pie. Picados de la curiosidad corren todos a saber quiénes sean, y es el cura, el más curioso de todos, y también el más metementodo, quien tira del hilo y desanuda la larga historia pendiente de Dorotea y Cardenio, de Lucinda y D. Fernando, con su anagnórisis a cuatro voces, y la feliz reordenación de las parejas. Apenas destrabados tan trabados negocios, los que han sido protagonistas se convierten en espectadores de una nueva historia no menos excitante: a la venta llegan un hombre que por su aspecto muestra ser un cristiano recién salido de tierra de moros, con sus borceguíes datilados y su alfanje, y una deslumbrante mora, que vela su rostro. Imagínense la curiosidad de todos, iy la del cura! Y cuando aún suspiran de emoción por la "novedad y extrañeza" de un caso en que "todo es peregrino y raro y lleno de accidentes que maravillan y suspenden a quien los oye", he aquí que arriba a la venta un coche del que salen un Oidor y su hija, con algunos hombres a caballo que les acompañan. Más emociones y más sorpresas y novedades: el Oidor resultará el hermano del Cautivo. Acabado un día tan intenso y cuando ya han dejado caer sus cansados huesos en la porción de cama o de suelo que les tocaba, y faltaba ya poco para que amaneciese, las mujeres se ven sobresaltadas por una voz maravillosa que canta una canción de amor, que no se corresponde con el aspecto de quien la canta, un aparente mozo de mulas. De nuevo una historia sobre la que lanzarse afanosamente hasta descubrir y admirar su secreto. Y desde este punto hasta el final de la estancia en la venta no habrá más que novedades: primero son "cuatro hombres a caballo, muy bien puestos y aderezados, con sus escopetas sobre los arzones"; más tarde es el barbero a quien don Quijote había arrebatado su yelmo y Sancho su albarda, y que al encontrarlos en la venta se precipita sobre Sancho llamándole ladrón y pidiendo favor a la justicia; por último llegan los cuadrilleros, uno de los cuales trae un mandamiento de prisión contra don Quijote, por la fuga de los galeotes.

En estos últimos capítulos de la estancia en la venta de Juan Palomeque el Zurdo, la escena se convierte en una confusa y alborotada asamblea. Los cuatro hombres armados quieren llevarse a don Luis, que se resiste y discute con 
ellos, en medio de las preguntas de los viajeros que quieren saber la causa de aquello, momento que aprovechan dos huéspedes para intentar marcharse sin pagar, pero el ventero, que está muy atento, les sale al paso, discuten, gritan, se van a las manos, repartiéndose puñadas y mojicones ante don Quijote, que los contempla con gran parsimonia, pese a los gritos de la ventera, de su hija y de Maritornes que le piden que ayude al ventero; mientras tanto el Oidor, como buen juez, se interesa por el asunto de D. Luis y pide explicaciones, que le da el joven, contándole la historia de su amor por su hija; el barbero de la bacía se echa sobre Sancho, que lo rechaza a puñadas, atrayendo la atención de don Quijote, que pasa a contemplar esta nueva pelea; todos los asistentes se ponen a discutir si se trata de un yelmo o de una bacía, de una albarda o de un jaez, y hay sus más y sus menos, y don Fernando pide votos a unos y a otros, si bien después de pactarlos en secreto, pero hay un cuadrillero que está fuera de juego y que jura que aquello es "tan albarda como mi padre", lo que provoca que don Quijote trate de callarlo de un solo golpe de lanza; ponen el grito en el cielo todos los cuadrilleros y cargan contra don Quijote, que echa mano a la espada; los criados de don Luis le rodean para evitar que con el tumulto se escape; "el cura daba voces; la ventera gritaba; su hija se afligía; Maritornes lloraba; Dorotea estaba confusa; Lucinda suspensa, y doña Clara desmayada. El barbero aporreaba a Sancho; Sancho molía al barbero; don Luís, a quien un criado suyo se atrevió a asirle del brazo porque no se fuese, le dio una puñada que le bañó los dientes en sangre; el Oidor le defendía; don Fernando tenía debajo de sus pies a un cuadrillero, midiéndole el cuerpo con ellos muy a su sabor; el ventero tornó a reforzar la voz, pidiendo favor a la Santa Hermandad... De modo que toda la venta era llantos, voces, gritos, confusiones, temores, sobresaltos, desgracias, cuchilladas, mojicones, palos, coces y efusión de sangre" (p. 525).

Más emociones, imposible. Ni más novedades tampoco.

Se ha repetido a menudo que la venta de Juan Palomeque es una representación metafórica de la vida (Avalle Arce ed. 1979, I, pp. 12-13), cosa que es exacta sólo hasta un cierto punto. Lo que se representa no es la vida en su conjunto. No hay en ella demasiado espacio para la intimidad, por ejemplo, ni momentos de una intensidad imaginativa como el vivido por don Quijote en la cueva de Montesinos, ni los sabrosos diálogos que en el camino intercambian Sancho y su señor... Lo que caracteriza a la experiencia en la venta es la cohabitación de unos y de otros y su participación conjunta como actores o como espectadores activos en las diferentes historias. Cuando Dorotea insta a don Fernando a que la acepte como esposa, dejando en libertad a Lucinda para que se reúna con su amado Cardenio, todos cuantos escuchan sus conmovedoras razones toman partido, añaden argumentos, especialmente el cura, que improvisa todo un sermón, derraman sus lágrimas junto con los protagonistas, hasta Sancho Panza llora, e imponen todos a don Fernando lo que el narrador no duda en llamar "la verdad", la verdad o la razón del amor, que al principio encarnaba Dorotea en su discurso y que ahora ha sido impuesta por todos. Don Quijote pronuncia su discurso sobre las armas y las letras en una mesa donde se ha servido una buena cena, y a la que se han sentado todos, y todos escuchan la 
historia de El curioso impertinente y la del Cautivo, y opinan sobre ellas, y ayudan a prevenir las dificultades que encontrará la bella mora en su adaptación a una patria y unas costumbres nuevas, y las que encontrará también el Cautivo, con su pobreza de soldado. Todos intervienen para que la historia de amor entre $\mathrm{D}^{\mathrm{a}}$ Clara y D. Luis no quede cercenada por las conveniencias sociales, ni tampoco dejada al azar, sin que nadie vele por ellos, y todos contribuyen al debate sobre el yelmo de Mambrino y después a sosegar ese gran tumulto que llega a encenderse, con la posterior confrontación entre don Quijote y la Santa Hermandad. Entre los viajeros que van congregándose en la venta se crean unos lazos de solidaridad muy especiales, y si la venta es el lugar de numerosos conflictos es también el lugar de su resolución, una resolución en la que los viajeros se reconocen mutuamente el derecho a opinar e intervenir. La venta deviene así una metáfora no de la vida en general, sino de la vida en su sociabilidad, una sociabilidad que se expresa como reflexión sobre las alianzas de la vida y la literatura y sobre el papel de ésta en la sociedad, lo que nos acerca a la imagen del libro; o como audiencia -de historias ocurridas, de discursos, de lecturas literarias, de representaciones teatrales-, y la imagen más semejante es la del teatro; pero también como controversia, por lo que lo más atinado sería un foro o un parlamento; y finalmente como acción, lo que remite la venta a la plaza pública. Libro, plaza, teatro o parlamento son las máscaras diversas que la sociabilidad se otorga en el escenario de las ventas cervantinas.

\section{BIBLIOGRAFÍA CITADA}

Accademia degli Intronati di Siena: Gl'Ingannati. Commedie del '500. A cura di Maria Luisa Doglio. Roma-Bari, Editori Laterza. 1975, pp. 311-397.

Alemán, Mateo: Guzmán de Alfarache. Ed. de F. Rico. Barcelona, Planeta. 1983

Alter, Robert : Partial Magic. The Novel as a Self-Conscious Genre. Berkeley, University of California Press. 1975.

Ariosto, Ludovico: Orlando furioso. Ed. bilingüe de Cesare Segre y $\mathrm{M}^{\mathrm{a}}$ de las Nieves Muñiz. Madrid, Cátedra. 2002, 2 vols

Atribuido a Vega, Lope de : La Ilustre fregona y amante al uso. Parte XXIV perfecta. Zaragoza, Pedro Verges, 1641. Ed. moderna en Obras de Lope de Vega, publicadas por la Real Academia Española (nueva edición). Edición de Emilio Cotarelo y otros. Vol. VI, 1928, pp. XXII-XXIII.

Avalle ArCe, Juan B. ed.: Cervantes, Miguel de: Don Quijote de la Mancha. Madrid. Alambra, 1979, 2 vols.

Bandello, Matteo: Le novelle. Ed. de Delmo Maestri de las cuatro partes. Alessandria, Edizioni dell'Orso, 1992-1996.

Cervantes, Miguel de: Don Quijote de la Mancha. Ed. del Instituto Cervantes, dirigida por F. Rico, Barcelona, Crítica, 1998, 2 vols.

Cervantes, Miguel de: La Ilustre fregona. Ed. de Jorge García López. Barcelona, Crítica. 2001, pp. 371-440.

Chaucer, Geoffrey: Canterbury Tales, Penguin Classics, Penguin Books, 1951.

CIFRE, Patricia: De la autoconciencia moderna a la metaficción posmoderna. Salamanca, Ediciones Universidad de Salamanca. 2003.

DOTRAS, Ana $\mathrm{M}^{\mathrm{a}}$.: La novela española de metaficción. Madrid, Júcar. 1994. 
Foucault, Michel: Les mots et les choses, une archéologie des sciences humaines. Paris, Gallimard. 1966.

García Martín, Manuel: Cervantes y la comedia española en el siglo XVII. Salamanca, Ediciones de la Univ. de Salamanca. 1980.

Hutcheon, Linda: A poetics of Postmodernism. History, Theory Fiction. New York \& London, Routledge. 1988.

Joly, Monique: La bourle et son interprétation. Espagne. 16/17e. Siècles. Toulouse, Université de Toulouse-Le Mirail. 1982

Ly, Nadine: "Don Quichotte: Livre d'aventures et aventures de l'écriture (Pour une sémiotique 'écriture) ». Les Langues Néo-latines, $\mathrm{N}^{\circ} 267,1988$, pp. 5-92.

MARÍN PINA, M.Carmen: “Lecturas del Quijote. Caps. II y III”, en Don Quijote de la Mancha. Ed. del Instituto Cervantes. Barcelona, Crítica, 1998. Vol. Complementario, pp. 18-23.

Morley, S.Griswold y Bruerton, Courtney: Cronoloigía de las comedias de Lope de Vega. Madrid, Gredos. 1968.

OlezA, Joan : "La comedia: el juego de la ficción y del amor", Edad de Oro, X, 1990, pp 203-220;

OlEZA, Joan: "Hagamos cosas de risa las cosas de calidad: El lacayo fingido, de Lope de Vega, o las armas sutiles de la Comedia", en VVAA, La puesta en escena del teatro clásico. Cuadernos del Teatro Clásico, $\mathrm{N}^{\circ}$ 8, 1995, pp.85-119

OlEzA, Joan: "Mesones de teatro", en Homenaje a Marc Vitse, Presses Universitaires du Mirail, Toulouse-Le Mirail, 2006.

OlEZA, Joan: "Un realismo posmoderno", $\mathrm{N}^{\circ}$ monográfico El espejo fragmentado. Ínsula, $\mathrm{n}^{\mathrm{a}}$ 589-590. Enero-febrero 1996, pp.39-42.

OLIVER Asín, Jaime: "Sobre los orígenes de La Ilustre fregona", BRAE, XV, 1928, pp. 224-231.

OREJAS, Francisco G.: La metaficción en la novela española contemporánea. Madrid, Arco Libros. 2003.

Pulci, Luigi: Morgante. Ed. a cura di Davide Puccini. Milano, Garzanti. 1989

RILEY, Edward C.: Teoría de la novela en Cervantes. Madrid, Taurus. 1966.

RIQUER, Martín de: "Don Quijote, caballero por escarnio", Clavileño, VII, 1956, pp. 47-50.

RuEDA, Lope de: Los engañados. Las cuatro comedias. Ed. de Alfredo Hermenegildo. Madrid, Cátedra. 2001, pp. 165-214 .

SACCHETTI, Franco: Il trecentonovelle. Ed. de Emilio G Faccioli. Einaudi, Torino, 1970.

SÁNCHEZ DE BADAJOZ, Diego: La Farsa de la ventera en que se representan algunos engaños que algunas suelen usar con que a las vezes roban a los caminantes. Recopilación en metro del Bachiller...Sevilla, 1554. Reproducida en facsímile por la Academia Española. Madrid. MCMXXIX. Fols. CXXXIIII-CXXXVI.

ShaKeSPeAre, William: The Merry Wives of Windsor. The First Part of King Henry The Fourth. The Second Part of... Las tres en The Complete Works of William Shakespeare. London. Abbey Library, s.a. pp. 53-78, 405-433, 434-464 respectivamente. Los pasajes traducidos en prosa castellana proceden de Luís Astrana Marín, en la edición de las Obras Completas. Madrid, Aguilar. 1943.

VEGA, Lope de: El mesón de la corte. . Ed. moderna en Obras de Lope de Vega, publicadas por la Real Academia Española (nueva edición). Edición de Emilio Cotarelo y otros. Vol. I. 1918.

VeGA, Lope de: La noche toledana. Parte III. Barcelona, 1612. Ed. moderna en Comedias de Lope de Vega. Parte III. Ed. de Agustín Sánchez Aguilar. Barcelona. Prolope, 2002, pp. 57-252.

VICENTE, Gil: Auto da alma, en Obras Completas de Gil Vicente. Reimpressão fac-similada da ediçao de 1562. Lisboa, 1928, fols. XXXVIII-XLII. 


\title{
Resumen
}

En estas páginas se recorre un itinerario que, a través de ventas y mesones, conduce desde los Canterbury Tales hasta el Quijote, en una geografía literaria europea. Se hace parada en las colecciones italianas de novelle (Sachetti, Bandello), en los poemas caballerescos del Renacimiento (Pulci, Ariosto), en el teatro del Quinientos (de Gil Vicente a Lope de Rueda, pasando por los Intronati de Siena), en la Comedia Nueva y en las comedias de mesón de Lope de Vega, en el teatro isabelino (Shakespeare sobre todo), en el Guzmán de Alfarache, en La ilustre fregona (novela y comedia), y así hasta el Quijote, en cuya multiplicada experiencia de ventas y caminos demoramos el paso. Nos acompaña siempre la interrrogación sobre el cambiante sentido de la venta como escenario donde se plasma todo un discurso sobre la vida y la literatura. En el caso del Quijote, verdadera culminación de todo este itinerario europeo, la venta adquiere una pluralidad de significaciones que la equiparan, de forma diversificada, a otros grandes instrumentos culturales: la calle, el libro, el foro, el teatro.

Palabras clave: ventas, literatura europea, Quijote, discursos

\begin{abstract}
On these pages travel from the Canterbury Tales to the Quijote going from inn to inn throughout a European literary geography. We stop and lodge in the italian series of novelle (Sacchetti, Bandello), in the Chevalry Poems of the Renaissance (Pulci, Ariosto), in the Sixteenth Century theatre (from Gil Vicente to Lope de Rueda and the Intronati di Siena), in the Comedia Nueva and especially in the comedias de mesón de Lope de Vega, in the Elizabethan Theatre (Shakesperare above all), in the Guzmán de Alfarache, in La ilustre fregona (the novel and also the commedy), and so on until the Quijote, where the multiple experience of inns and roads is closely examined. At every stop I reflecton the changing sense of the inn as the stage where a whole discourse on life and litterature is being shaped. In the particular case of Don Quijote, a real culmination point of all that european journey, the inn manages to gather a multiplicity of meanings that rank it with other great cultural instruments: the street, the book, the forum, the theatre.
\end{abstract}

Key words: Inns, European litterature, Quijote, Discourses. 